Review

\title{
Harvesting Carbon from Eastern US Forests: Opportunities and Impacts of an Expanding Bioenergy Industry
}

Sarah C. Davis ${ }^{1,2, *}$, Michael Dietze ${ }^{1,2}$, Evan DeLucia ${ }^{1,2}$, Chris Field $^{3}$, Steven P. Hamburg ${ }^{4}$, Scott Loarie ${ }^{3}$, William Parton ${ }^{5}$, Matthew Potts ${ }^{6,7}$, Benjamin Ramage ${ }^{6}$, Dan Wang ${ }^{2}$, Heather Youngs ${ }^{7}$ and Stephen P. Long ${ }^{1,2,8}$

1 Department of Plant Biology, University of Illinois Urbana-Champaign, Urbana, IL 61820, USA; E-Mails: mdietze@life.uiuc.edu (M.D.); delucia@uiuc.edu (E.D.); slong@uiuc.edu (S.P.L.)

2 Energy Biosciences Institute, University of Illinois Urbana-Champaign, Urbana, IL 61820, USA; E-Mail: dwng@illinois.edu

3 Department of Global Ecology, Carnegie Institute for Science, Stanford, CA 94305, USA; E-Mails: cfield@ciw.edu (C.F.); loarie@gmail.com (S.L.)

4 Environmental Defense Fund, Boston, MA 02108, USA; E-Mail: shamburg@edf.org

5 Natural Resources Ecology Laboratory, Colorado State University, Fort Collins, CO 80521, USA; E-Mail: billp@nrel.colostate.edu

6 Department of Environmental Science Policy and Management, University of California Berkeley, Berkeley, CA 94720, USA; E-Mails: mdpotts@berkeley.edu (M.P.); bsramage@berkeley.edu (B.R.)

7 Energy Biosciences Institute, University of California Berkeley, Berkeley, CA 94720, USA; E-Mail: hlyoungs@berkeley.edu

8 Department of Crop Sciences, University of Illinois Urbana-Champaign, Urbana, IL 61820, USA

* Author to whom correspondence should be addressed; E-Mail: davissc@illinois.edu; Tel.: +1-217-244-5952.

Received: 30 March 2012; in revised form: 26 May 2012 / Accepted: 8 June 2012 / Published: 19 June 2012

Abstract: Eastern forests of the US are valued both as a carbon sink and a wood resource. The amount of biomass that can be harvested sustainably from this biome for bioenergy without compromising the carbon sink is uncertain. Using past literature and previously validated models, we assessed four scenarios of biomass harvest in the eastern US: partial harvests of mixed hardwood forests, pine plantation management, short-rotation woody cropping systems, and forest residue removal. We also estimated the amount and location of abandoned agricultural lands in the eastern US that could be used for biomass production. Greater carbon storage was estimated to result from partial harvests and 
residue removals than from plantation management and short-rotation cropping. If woody feedstocks were cultivated with a combination of intensive management on abandoned lands and partial harvests of standing forest, we estimate that roughly $176 \mathrm{Tg}$ biomass $\mathrm{y}^{-1}$ ( $\sim 330,000 \mathrm{GWh}$ or $\sim 16$ billion gallons of ethanol) could be produced sustainably from the temperate forest biome of the eastern US. This biomass could offset up to $\sim 63 \mathrm{Tg} \mathrm{C} \mathrm{y}$ that are emitted from fossil fuels used for heat and power generation while maintaining a terrestrial $\mathrm{C}$ sink of $\sim 8 \mathrm{Tg} \mathrm{C}^{-1}$.

Keywords: biofuel; woody biomass; forest management; residue; logging; temperate forest; sustainability; CHP; greenhouse gas reduction; carbon dioxide emission; carbon sequestration

\section{Introduction}

Increasing demand for cellulosic feedstocks for biofuels and electricity generation has led to federal legislation that incentivizes both biomass removal from forests and cultivation of short-rotation woody crops $[1,2]$. Woody biomass is an attractive feedstock because it can be harvested year-round and supplies are far less vulnerable than herbaceous feedstocks to adverse weather conditions (e.g., drought) in a given year. Forests of the eastern US provide valuable wood resources, but also provide many ecosystem services including greenhouse gas (GHG) mitigation. The period of forest regeneration that followed wide-scale logging and agricultural abandonment (due to the Civil War and Great Depression) resulted in a large terrestrial carbon (C) sink in the eastern US [3], and much of this $\mathrm{C}$ is stored in aboveground biomass. Today, most forestland in the eastern US is privately owned and harvested at highly variable intervals. In fact, industrial forestlands represent only $11 \%$ of US forestland [4] and 15\% of wood biomass [5]. Despite political mandates to increase woody biomass production, there are many unanswered questions about the environmental and economic impacts of intensifying the management of wood resources.

We investigated the resource potential and ecological impacts of harvesting biomass from different wood sources in eastern forestlands of the US. Even though the largest standing stock of forest $\mathrm{C}$ in the US is in the northwest, a recent meta-analysis concluded that the eastern US includes forests that are both the strongest sink of atmospheric $\mathrm{C}$ and the strongest source of forest $\mathrm{C}$ to the atmosphere in the nation, depending on location and management [6]. The northern forest region, that includes both the northeast and Great Lakes region, is currently a net sink of $66 \mathrm{Tg} \mathrm{C} \mathrm{y}{ }^{-1}$ ( $\mathrm{C}$ removed from the atmosphere), while the southeast is a net source of $-7 \mathrm{Tg} \mathrm{C} \mathrm{y}^{-1}(\mathrm{C}$ emitted to the atmosphere) [6]. Immediate and complete harvest of eastern US forests ( $\sim 10 \mathrm{Pg}$ of standing biomass or $\sim 5 \mathrm{Pg} \mathrm{C})$ [7] would not be sustainable because of the time required to recover $\mathrm{C}$ stocks (for example $5 \mathrm{Pg} \mathrm{C} / 66 \mathrm{Tg} \mathrm{C}$ $\mathrm{y}^{-1}=76 \mathrm{y}$, or $5 \mathrm{Pg} /-7 \mathrm{Tg} \mathrm{C} \mathrm{y}{ }^{-1}=$ infinite time to recover), habitat, and ecosystem services (water quality, recreation, etc.). Given that much of the region is a net $\mathrm{C}$ sink, an open question is: how much biomass can be harvested sustainably to offset fossil fuel demands?

Although the primary location for $\mathrm{C}$ sequestration (uptake) in most bioenergy cropping systems is in the soil [8-10], the $\mathrm{C}$ sequestration of forested systems in much of the eastern US is primarily in 
aboveground woody material [11-13]. Thus, wood resources are often managed with partial harvests where only a portion of the biomass is removed at any given time so that some aboveground biomass is always maintained. Low intensity (smaller percentage removed) and low frequency (longer time intervals between removals) harvests can result in less change to the $\mathrm{C}$ balance of a forest ecosystem $[14,15]$. Trade-offs between lower intensity harvests from the large aboveground $\mathrm{C}$ pool of forests and short-rotation systems that often store soil C [16] have not been fully evaluated.

Residues from current forest management can provide an additional bioenergy feedstock source. In fact, forest biomass that is currently used for energy frequently comes from material that would decay quickly if left in the forest (e.g., logging residues) [17]. Thus, forests that are managed for biomass alone or managed for both conventional wood products and biomass co-products may result in climate benefits $[18,19]$. Potential residue feedstocks include limbs and tops, small-diameter trees, downed logs, stumps, shrubs and litter/duff material that would otherwise remain in the forest after a timber harvest. Many of the current forest management guidelines, usually termed "best management practices," do not provide definitive rules on the removal of these lower-value sources of woody biomass, in part because there are still many unanswered questions about the long-term effects of such extractions [20,21].

Marginal and recently abandoned lands have been proposed as potential locations for cultivating biofuel feedstocks to avoid competition with high-yielding agriculture and forestry. There are varying definitions of marginal and abandoned lands but generally they are lands which cannot support economically viable production of row crops or intensive forestry because of soil quality, soil degradation or impractical location. Some wooded areas of the eastern US fit this definition [22]. Timber production in the southeastern US, for example, has been abandoned in some areas due to degraded soils and yield losses over time. These areas might support high-yielding perennial grasses and short-rotation woody cropping systems that are proposed as biofuel crops and also sequester soil C [8,16,23-25], but some abandoned lands have become large forest $\mathrm{C}$ stocks. To optimize environmental benefits from bioenergy development on abandoned lands, it is essential to distinguish recently abandoned lands from abandoned lands that now support regenerated forests.

This study is the first to evaluate the sustainability of potential bioenergy production from eastern US forests based on demonstrated harvesting practices and measured land resources. There have been a number of recent works that describe environmental impacts of biomass harvest from forests within a state or a region [20,26,27]. We rely heavily on previous literature for our analysis, but we synthesize these existing data to specifically address the potential for bioenergy production in the region that is the nation's largest terrestrial C sink, the eastern US [6,28].

We evaluated the environmental sustainability and greenhouse gas mitigation potential of four scenarios of biomass harvest in the eastern US using data from previously published literature and previously validated modeling tools that simulate biomass yields and $\mathrm{C}$ budgets. The scenarios range in management intensity to include (1) partial harvest from secondary forests in the northeast; (2) pine plantations in the southeast; (3) short-rotation woody crops in the Great Lakes region; and (4) residue managements across the entire eastern forest region. We then estimated the potential biomass production on abandoned lands in the eastern US for each of these scenarios. The final discussion briefly summarizes broader sustainability objectives (economic, energy security) that affect biomass production from the forested region of the Eastern US. 


\section{Methods}

The scope of our review is constrained by assumptions about spatial scale, production chain boundaries, and temporal scales. Literature reviews of each scenario were conducted with a regional boundary defined, but model estimates reflect site-level $\mathrm{C}$ dynamics. Model simulations were used to illustrate temporal dynamics of $\mathrm{C}$ fluxes under a specific management practice. Environmental processes (e.g., biodiversity, water, habitat) affected by the spatial distribution of harvesting practices were not quantified. The boundary of the theoretical bioenergy production system evaluated in each scenario was limited to include only water inputs, nutrient inputs and harvesting practices that occur prior to processing biomass feedstocks for energy or fuel. The end use could be solid or liquid fuel. Logging equipment and transportation of biomass were considered only generally to distinguish between scenarios where biomass has already been transported (e.g., mill residues), scenarios with existing infrastructure to transport biomass (e.g., diversion of wood resources), and scenarios where new machinery and transportation demands would need to be met.

\subsection{Overview of Biomass Production Scenarios}

\subsubsection{Scenario \#1: Partial Harvest of Biomass from Secondary Hardwood Forests}

Secondary hardwood forests are managed with a number of different methods. Careful single tree selection cutting (that avoids "high-grading" or the selective removal of only the most valuable trees) is considered one of the most sustainable methods because it maintains species composition, forest biomass, and C sequestration over time [29]. No fertilizers or irrigation are typically applied to the forest and very little management is required between harvest events. Specialized equipment and skilled labor are required to extract biomass at multiple entry points. In forestlands of the eastern US, this management is most common in the northeastern region (primarily in Maine, New Hampshire, Vermont, Massachusetts, Connecticut, Rhode Island, New York, Pennsylvania, and West Virginia).

\subsubsection{Scenario \#2: Harvesting Biomass from Pine Plantations}

There are active and abandoned pine plantations, many dominated by Pinus taeda (loblolly pine), across much of the southern piedmont and coastal plain [30]. These forests could be either reclaimed if abandoned or diverted from pulp and paper products to biomass production if active. Irrigation and fertilizer are sometimes used in this intensive management system that typically includes complete harvests every $12-20 \mathrm{y}$.

\subsubsection{Scenario \#3: Short-Rotation Woody Cropping Systems}

Short-rotation woody crops are often comprised of poplar or willow species and can provide a consistent yield in a shorter turnaround time than pine plantations (3-13 y) [16]. Fertilizer and sometimes irrigation are applied with this management practice and all aboveground biomass is removed at harvest. In the eastern US, this management is currently most common in the Great Lakes region (primarily in Michigan, Minnesota, and Wisconsin). 


\subsubsection{Scenario \#4: Forest Residues}

Woody residues appropriate for bioenergy applications are created in a variety of operations. We defined forest residues to include logging slash (some bark, tree tops, limbs and leaves, etc.), thinning and tree removals associated with logging, clearing and fire treatments, or any other forest removals that are not directly associated with roundwood harvest [31]. Primary mill residues are the bark and wood remainders resulting from mill processing of stem wood into products such as boards or paper, and include sawdust, trimmings, cores, and pulp screenings [32]. Secondary mill residues are remainders following the use of wood in construction, manufacturing and retail (lumber yards). Urban residues include municipal solid waste (pallets, yard waste, chipped wood), utility trimmings, private tree company trimmings, and construction and demolition wood [33].

\subsection{Approach to Synthesis}

A literature review of empirical data was conducted to characterize management practices, nutrient requirements, $\mathrm{C}$ balances and growth rates for each of the biomass production systems described above. A general discussion about management costs and benefits was developed. Input requirements were reviewed and the response of biomass production to different inputs was quantified for each scenario.

We analyzed scenarios 1-3 over two time periods. A short-term boundary was set to 11 y to estimate biomass harvest through 2022 and the long-term boundary was set to $60 \mathrm{y}$. These timelines were chosen to correspond to policy mandates, i.e., Renewable Fuel Standard [1], and the time it takes for abandoned land to reach a stage with late successional trees comprising half of the forest canopy (e.g., [34]), respectively.

After the initial evaluation based on scientific literature, we used the ecosystem models PnET (Photosynthesis Evapotranspiration) [35-39] and ED (Ecosystem Demography) [40-42] to simulate scenarios 1 through 3 in applicable regions of the eastern US. These modeling tools allowed us to estimate forest productivity dynamically while also partitioning wood production, soil $\mathrm{C}$, and net $\mathrm{C}$ sequestration. Net $\mathrm{C}$ sequestration was further partitioned into photosynthetic $\mathrm{C}$ uptake, $\mathrm{C}$ losses through autotrophic and heterotrophic respiration, and $\mathrm{C}$ losses from harvested biomass.

The PnET model parameterization for scenario 1 (partial harvest from secondary forests) was based on previous work that calibrated the model for a mixed hardwood forest in the Fernow Experimental Forest in Parsons, WV, USA [37], and validated model estimates against hardwood forests with different harvesting histories [14]. PnET has been used previously to estimate loblolly pine production in the southeastern US [30,43], and thus we also used this model to simulate scenario 2. Parameterization of PnET for scenario 2 (pine plantations) was based on measurements made along a chronosequence of loblolly pine stands in the Duke Forest in Chapel Hill, NC, USA [34].

The ED model has been used to estimate the yields and ecosystem service impacts of short-rotation cropping systems of hybrid poplar for the contiguous United States [44]. ED was calibrated by combining a broad literature meta-analysis of Populus (poplar) ecophysiology with a data-assimilation approach for yield trials involving two clones and three planting densities at Rhinelander, WI, USA [45]. ED was then verified against observed data from six other sites (WA, MO, SD, WI, MN, ND) 
with 3-4 clones in each site $[46,47]$. Model simulations for short rotation woody crops were based on a 4 y or 8 y rotation cycle at Mondovi, WI, USA.

Abandoned agricultural lands were identified using historical land use data from the History Database of the Global Environment 3.0 (HYDE, 5-min spatial resolution) [48,49]. Gridded maps from HYDE provided the fractional crop area and the fractional pasture area within each grid cell for each decade from 1700 to 2000 . These maps were used to derive estimates of the amount of abandoned agriculture in each grid-cell $(5 \times 5 \mathrm{~min})$ expressed as a percentage of area. To accommodate uncertainty in the contributions of transitions between crops and pasture to abandonment, we used upper and lower extreme estimates. The methods that produced these estimates are described in depth elsewhere [22]. Briefly, grid-cells undergoing abandonment were classified as grid-cells with decreasing agriculture over time. For the lower bound on estimates, concurrent increases in crop area and decreases in pasture area and vice-versa were considered transitions and did not constitute net contributions to the abandoned area. For the upper bound estimates, the area of abandoned agriculture was considered the sum of the area of abandoned pasture and abandoned crops which was then subtracted from the minimum areas attained across the time series. MODIS data were used to exclude urban areas from the analysis.

To calculate the area of abandoned lands in the eastern US, we intersected the boundaries of the United States with eastern coniferous and deciduous forest biomes from the World Wildlife Fund ecoregions [50] to derive a 267.3 Mha estimate of the size of the forested biome in the eastern US. We then calculated the area of abandoned agriculture in this region using the assumptions described above. The amount of abandoned land was then estimated more specifically for the northeast, Great Lakes region, and the southeast so regionally appropriate scenarios of biomass production could be analyzed. Final estimates of potential biomass production were based on the area of abandoned land in each region and the wood production estimated for a given scenario.

\section{Results and Discussion}

\subsection{Scenario 1}

\subsubsection{Scenario 1 Literature Review: Partial Harvest from Secondary Hardwood Forests}

Low intensity biomass management practices in forests (partial harvest of site, e.g., single-tree selection, diameter limit cutting or patch cutting of a landscape) do not require inputs of fertilizer or irrigation that are characteristic of more intensive biomass production systems. This is one reason that best management practices (BMPs), which are regulated at the state level and usually voluntary, point to lower intensity harvesting as a means to preserve water quality and other ecosystem services (e.g., [27]. The mean biomass removal for low-intensity diameter-limit cutting in mixed hardwood forests with mature sawtimber is $\sim 17 \%$ of the total aboveground biomass [14,26,29]. Although the harvest interval usually varies, 15-year intervals between low intensity harvests are common [15,29].

Previous studies that evaluate partial harvests relative to other managements generally conclude that increasing harvest intensity has a negative effect on forest $\mathrm{C}$ sequestration $[14,15,18,51]$. These studies assume site-level comparisons where a partially harvested site, for example, is compared to a site that was entirely clear-cut (e.g., [14,15]). These are informative for understanding harvest impacts, but 
must be evaluated in a slightly different context when considering landscape level processes. For example, at a landscape level, the impact of clear-cutting $17 \%$ of the forestland relative to denuding the entire landscape may be comparable to the difference estimated at the site-level between partial harvests and clear-cuts. Impacts of patch clear-cutting in larger woodsheds (the area that supplies a commercial wood mill) may be similar to partial harvests at the site-level, but patch clear-cutting requires long-term landscape planning to maintain aboveground biomass, $\mathrm{C}$ and community structure. Analysis of partial harvesting at the site level serves only as a proxy for landscape dynamics.

It is also evident that net $\mathrm{C}$ storage depends on the end-use of biomass that is harvested from the forest $[15,18,52]$. It has been estimated that biomass use for bioenergy results in greater $\mathrm{CO}_{2}$ emissions than the use of biomass for wood products [52], mostly because wood products have a longer residence time than biomass that is immediately combusted for energy or heat. Thus, economic conditions and $\mathrm{C}$ residence times of harvested products can affect the sustainability of partial harvests from mature secondary forests [15].

\subsubsection{Scenario 1: Model Simulation Results}

We simulated the partial harvest of a mature mixed hardwood forest at $15 \mathrm{y}$ intervals using a version of the PnET model [35,36,38,39], PnET- $\mathrm{CN}_{\text {sat }}$ [37] which has been used to simulate different harvesting practices in the Fernow Experimental Forest, WV [14]. The simulated forest is assumed to be unmanaged (with no harvest events) for $100 \mathrm{y}$ prior to harvest simulations, with mixed age classes and high species diversity that is typical of temperate hardwood forests. We estimated annual wood production and net $\mathrm{C}$ sequestration assuming partial harvests with removal rates of $10 \%, 17 \%, 34 \%$, or $51 \%$ of aboveground biomass. Only the removal rates varied, not the intervals between harvests. This allowed us to isolate the effect of increasing harvest intensity (although an interaction between harvest interval and intensity does exist). Net $\mathrm{C}$ sequestration included net biomass and soil accumulation as well as $\mathrm{C}$ emitted as a result of the final end use as bioenergy.

Modeled wood production in response to partial harvesting was maintained over a $60-\mathrm{y}$ simulation period, with periodic fluctuations in response to harvest and climate variation (Figure 1a). Net $\mathrm{C}$ storage in forest biomass and soil increased over the sixty year period with $10 \%, 17 \%$, or $34 \%$ biomass removal events, but the managed ecosystem only remained a net sink of $\mathrm{C}$ throughout the entire $60-\mathrm{y}$ simulation period in the case of $10 \%$ and 17\% removals (Figure 1b). Removals of 34\% biomass resulted in a gradual gain of $\mathrm{C}$ over the long-term, but was still a net source of $\mathrm{C}$ to the atmosphere after $60 \mathrm{y}$. In contrast, removals of $51 \%$ caused the forest to be a net source of $\mathrm{C}$ to the atmosphere throughout most of the simulation period (Figure 1b).

Model simulations were parameterized for a forest in West Virginia, near the southern boundary of the northeast region, but the forest biomass estimated is comparable to that of forests in other parts of the northeast. The average biomass simulated before harvest was $\sim 100 \mathrm{Mg} \mathrm{ha}^{-1}$. Excluding Maine, which has a much lower mean merchantable biomass of $53 \mathrm{Mg} \mathrm{ha}^{-1}$ as a result of extensive management, the mean biomass reported for the other northeastern states is $\sim 101 \mathrm{Mg} \mathrm{ha}{ }^{-1}$, ranging from $91 \mathrm{Mg} \mathrm{ha}^{-1}$ in New Hampshire to $115 \mathrm{Mg} \mathrm{ha}^{-1}$ in Connecticut, which has limited forest management [26]. The level of active management of forests throughout the northeast varies widely, 
but responses to harvest that were estimated for West Virginia should apply to mixed hardwood forests across the region.

Figure 1. Simulated wood production (a) and net $\mathrm{C}$ storage (b) of a $\sim 100$ y old mixed hardwood forest with partial harvests every 15 years at varied intensities: 10\% removal (blue), 17\% removal (red), 34\% removal (purple), and 51\% removal (orange).

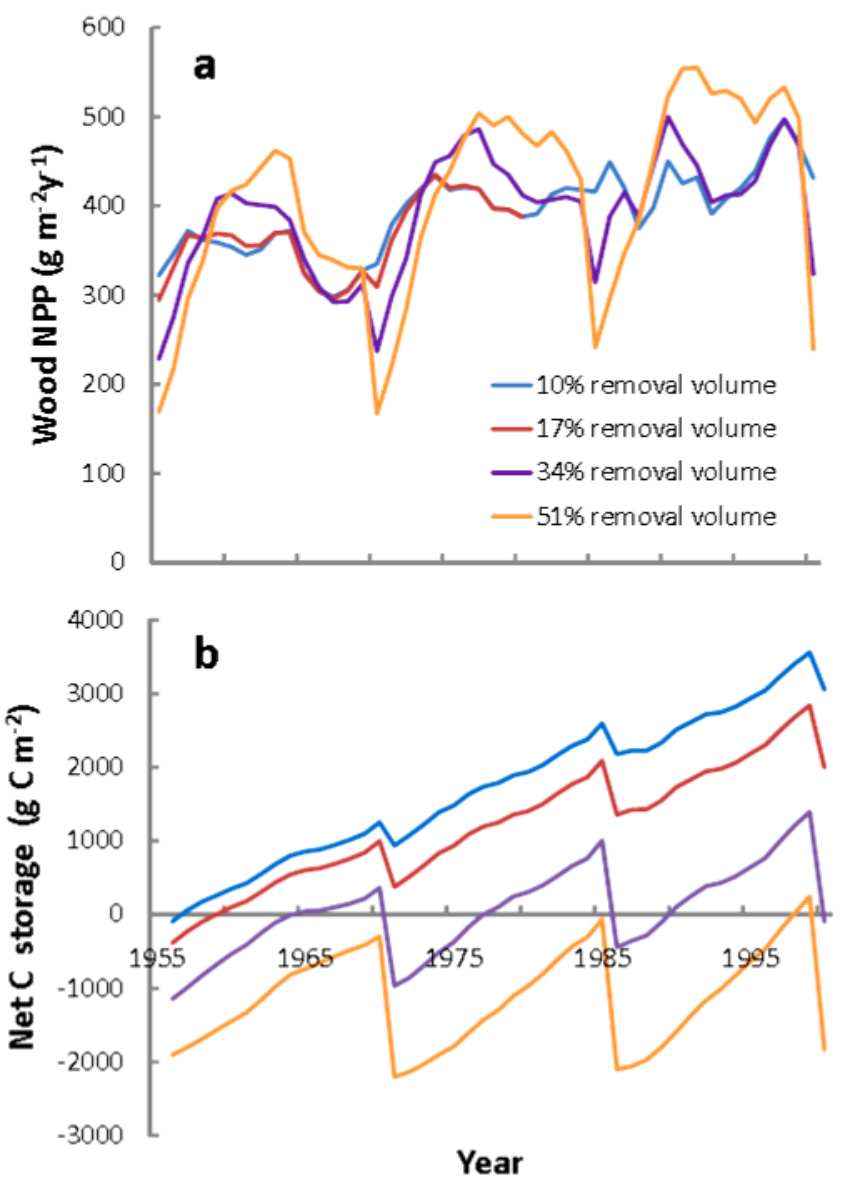

\subsection{Scenario 2}

\subsubsection{Scenario 2 Literature Review: Pine Plantations}

Fertilizers are often used in more intensively managed forestry production, i.e., plantations and short-rotation woody cropping systems. Irrigation is used infrequently (usually only at the time of planting) but sometimes supplements precipitation during periods of drought. We analyzed results from 24 forested sites measured in 13 independent studies of loblolly pine plantations in the southeastern US [53-64] to determine the effect of water (including both precipitation and irrigation), nitrogen $(\mathrm{N})$, and phosphorus $(\mathrm{P})$ inputs on biomass production. Using a 3-way ANOVA, we tested the effects of water, N, P, and the interactive effects of these variables on annual wood growth of loblolly pine plantations.

Based on literature, we found that annual wood growth was significantly affected by the interaction of phosphorus and water inputs $(p=0.0320)$ as well as the interaction of phosphorus and nitrogen inputs $(p=0.0253)$. The interactive effect of all three variables was not significant $(p=0.1976)$. 
If each variable was considered separately, the main effects of water and $\mathrm{P}$, while very small, were both significant $\left(p_{\text {water }}=0.0396, p_{\mathrm{P}}=0.0345\right.$; Figure 2$)$ but the effect of $\mathrm{N}$ alone was not $(p=0.1137$; Figure 2). Irrigation in managed loblolly pine plantations accounted for only $14 \%$ of total water inputs on average. Thus, $\mathrm{P}$ appears to be the most important input to loblolly pine plantations for increased growth, although the effect of $\mathrm{P}$ depends on $\mathrm{N}$ additions $\left(p_{\mathrm{pxn}}=0.0253\right)$. The range of $\mathrm{P}$ and $\mathrm{N}$ that was applied in the studies analyzed here was $8-112 \mathrm{kgP} \mathrm{ha}^{-1} \mathrm{y}^{-1}$ and $36-195 \mathrm{kgN} \mathrm{ha}^{-1} \mathrm{y}^{-1}$, respectively. This range describes experimental fertilizer applications and does not necessarily characterize the most common practices in pine plantations.

Figure 2. Annual growth response of loblolly pine plantation to water inputs (a) nitrogen fertilizer; (b) and phosphorus fertilizer; (c) $p$-values describe main effects from the treatment shown in each panel from a full factorial 3-way ANOVA where the interactive effects of water $x$ phosphorus and nitrogen $\times$ phosphorus were also significant $(p<0.05)$. Dotted line indicates no significant correlation. Solid lines indicate a significant correlation $(p<0.05)$.

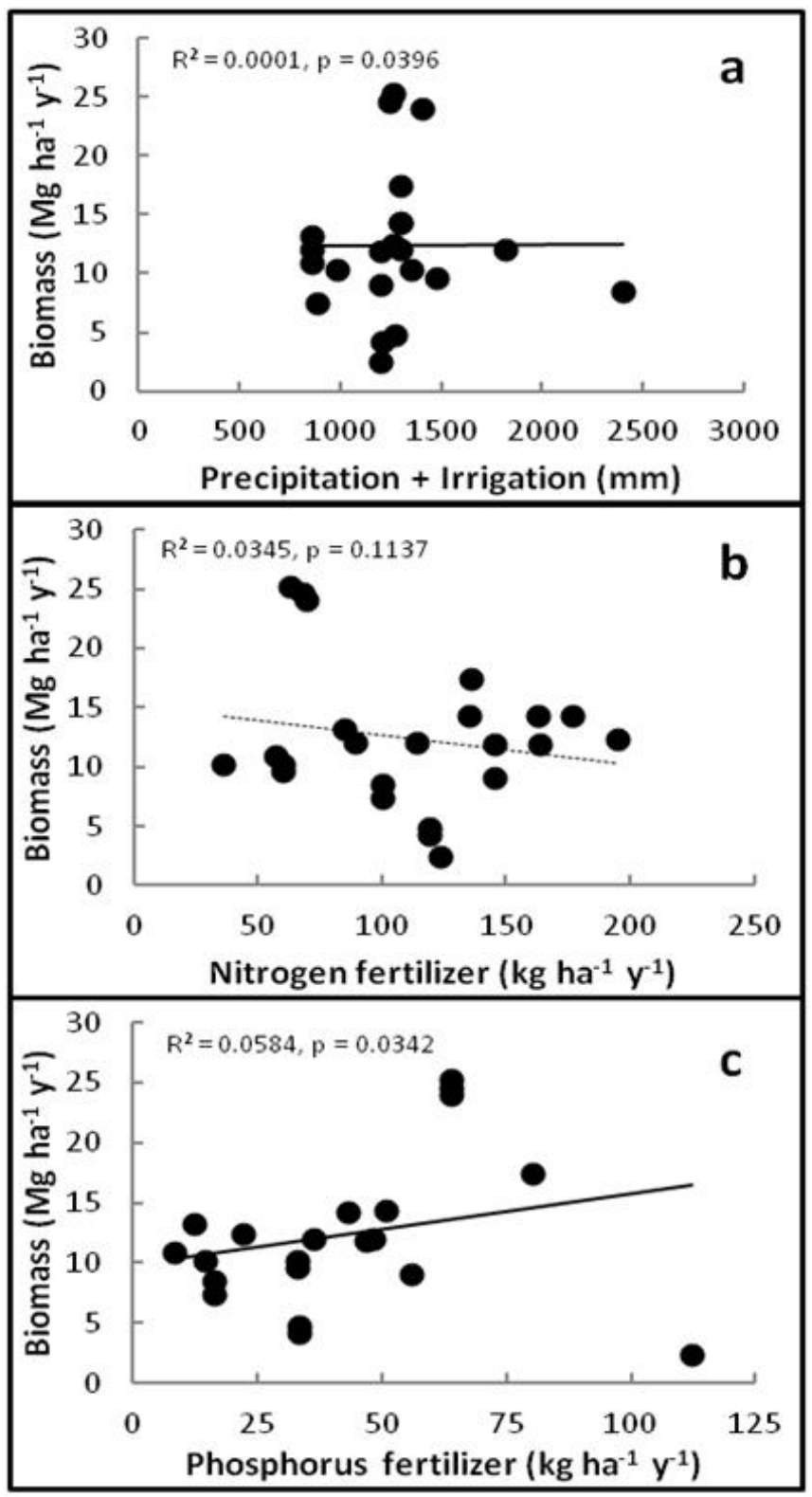




\subsubsection{Scenario 2: Model Simulation Results}

We simulated annual wood production and net $\mathrm{C}$ stored in pine plantations that were completely harvested at either 12 or $20 \mathrm{y}$ intervals using the PnET-II version of the PnET model. PnET-II has been used to simulate pine production in the southeastern US [30,43]. The simulation assumed no manipulations of water, $\mathrm{N}$, or $\mathrm{P}$. Wood production was maintained at a mean of $\sim 7 \mathrm{Mg} \mathrm{ha}^{-1} \mathrm{y}^{-1}$ during three harvest cycles that were simulated over $60 \mathrm{y}$ (data not shown), but wood production declined to a mean of $\sim 4 \mathrm{Mg} \mathrm{ha}^{-1} \mathrm{y}^{-1}$ in response to 12 -y harvest cycles over the $60 \mathrm{y}$ period (Figure $3 \mathrm{a}$ ). This loss could be offset by nutrient additions, which, if optimized, could stimulate long-term production by up to $32 \%$ (Figures $2 \mathrm{c}$ and $3 \mathrm{a}$ ). Without this nutrient supplementation, net $\mathrm{C}$ storage (including net biomass and soil accumulation as well as $\mathrm{C}$ emitted as a result of the final end use as bioenergy) declined over the $60 \mathrm{y}$ with a $12 \mathrm{y}$ harvest rotation (Figure $3 \mathrm{~b}$ ) as well as with a 20 -y harvest rotation. In the near-term, the pine plantation was a sink of $\mathrm{C}$, but the long-term perspective indicates that the system will become a net source of $\mathrm{C}$ to the atmosphere if harvests continue at regular intervals.

Figure 3. Simulated wood production (a) and C storage (b) in an abandoned loblolly pine plantation (no harvest- solid line) and a plantation harvested and replanted at $12 \mathrm{y}$ intervals (dashed line). The dotted line indicates $\mathrm{C}$ sequestration in soil only, and shaded dashed lines represent the potential production (a) and $\mathrm{C}$ storage (b) if fertilizer applications were optimized.

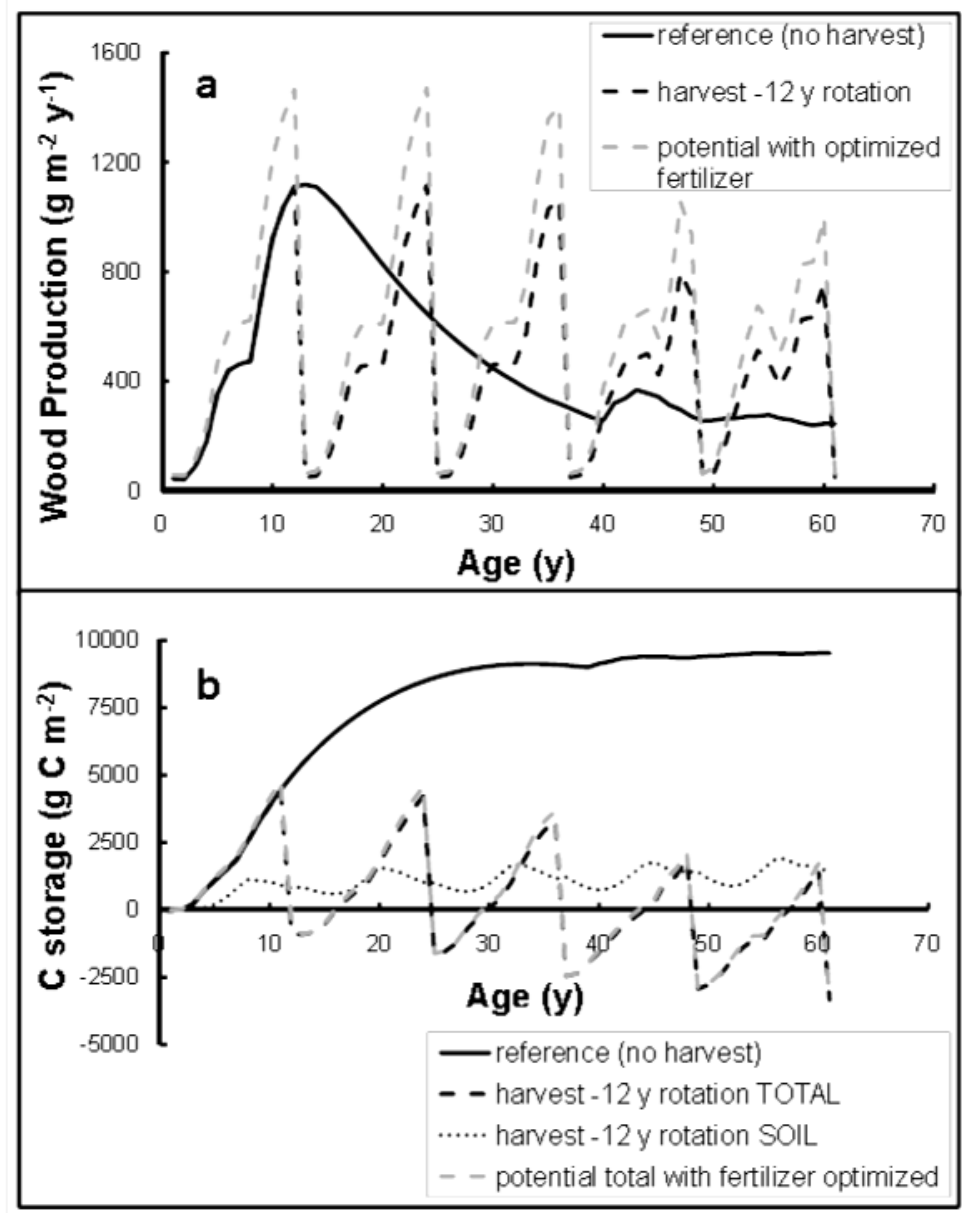


Noteworthy is that this scenario of a clear-cut plantation assumed that the same site was repeatedly and completely harvested at each interval. This should be distinguished from landscape-level patch cutting that uses clear-cuts at this frequency on only a small portion of the land while the remainder and majority is left un-harvested. In this landscape design, an individual land parcel can be un-harvested for $\geq 80$ y between clearing events.

\subsection{Scenario 3}

\subsubsection{Scenario 3 Literature Review: Short Rotation Woody Cropping}

Fast growing broadleaf trees such as Populus spp. (poplar) and Salix spp. (willow) and inter-specific hybrids, are the most common species considered as short-rotation woody crops [65-67]. In this system, known as short-rotation coppice, monocultures of these species or hybrids are planted, cut to the ground after 3-20 y, and then allowed to re-grow. Yields following coppice are typically much greater than in the first cycle, since re-growth is fueled from reserves in the root system. When considering areas that intersect with eastern US forestland, short-rotation woody crops are most common in the Great Lakes region. Because most data for this system have been collected outside of the eastern US, this section of our review first summarizes general observations of large scale field trials conducted in temperate zones of Europe and the Pacific Northwest, summarizing the main factors impacting yield. We then focus on the potential production and sustainability of short rotation woody crops specifically in the Great Lakes Region.

A review of historic data (available in the Biofuel Ecophysiological Traits and Yield Database (BETY-db [68]), collected from 11 countries for poplar, and 5 countries for willow, indicated a wide range in yields of poplar and willow. Averaged globally, poplar and willow have a mean annual growth of $7.1(\mathrm{n}=663, \mathrm{sd}=4.7)$ and $7.3(\mathrm{n}=349, \mathrm{sd}=4.5) \mathrm{Mg} \mathrm{ha}^{-1} \mathrm{yr}^{-1}$, respectively. In the US, similar yields of $7.7(\mathrm{n}=277, \mathrm{sd}=4.5)$ and $9.4(\mathrm{n}=68, \mathrm{sd}=3.8) \mathrm{Mg} \mathrm{ha}^{-1} \mathrm{yr}^{-1}$ have been achieved for poplar and willow, respectively. The annual growth of poplar varied greatly across different climates, soils and also depended on the choice of clones and initial planting densities. In the northwestern US, annual growth ranged from 11.4 to $24.3 \mathrm{Mg} \mathrm{ha}^{-1} \mathrm{yr}^{-1}$ in 4-year-old poplar stands under different planting conditions $[46,69,70]$. The yield of 4 y old hybrid poplars in Puyallup, WA was $35 \mathrm{Mg} \mathrm{ha}^{-1}[70]$. In the lower Midwest USA, poplar clones yielded up to $70 \mathrm{Mg} \mathrm{ha}^{-1}$ over 5 years $\left(14 \mathrm{Mg} \mathrm{ha}^{-1} \mathrm{y}^{-1}\right.$ ) without irrigation and fertilization [71]. There has been considerable recent effort to breed for sustainable higher yielding varieties of both poplars and willows, and a continued improvement in yield for this system should be expected [72].

Although there are fewer examples of poplar and willow crops in the eastern US relative to other parts of the world, they are considered a potentially important biomass crop for the region [73]. In the Great Lakes Region, annual growth of poplar ranged from 3.5 to $12.8 \mathrm{Mg} \mathrm{ha}^{-1} \mathrm{y}^{-1}$ [45,47]. Many poplar stands in the Great Lakes region are harvested at an older age (9 y) relative to those discussed above. Field trials of willow plantations have mostly been conducted in the UK to date, where the average annual growth is $8.1 \mathrm{Mg} \mathrm{ha}^{-1} \mathrm{y}^{-1}$ [74]. There was however a willow trial in Tully, NY, USA where the annual growth was $16.3 \mathrm{Mg} \mathrm{ha}^{-1} \mathrm{y}^{-1}$ for a willow clone (SV1) in its fifth growing season [75]. Over a three-year period in the Great Lakes region, another willow clone (Sx-61) has an 
annual growth of $12.7 \mathrm{Mg} \mathrm{ha}^{-1} \mathrm{y}^{-1}$ [76]. New hybrids of willow are currently being developed in the US for bioenergy and are expected to have even greater yields (e.g., [77]).

Based on literature, we found that the annual growth of poplar and willow was positively correlated with annual precipitation and was not affected by $\mathrm{N}$ fertilization (Figure 4). Thus, water availability appeared to be the key factor impacting production of poplar and willow crops. The range of $\mathrm{N}$ that was applied in the studies analyzed here was $50-336 \mathrm{kgN} \mathrm{ha}^{-1} \mathrm{y}^{-1}$ for poplar and $10-336 \mathrm{kgN} \mathrm{ha}^{-1} \mathrm{y}^{-1}$ for willow. Although there is no evidence that $\mathrm{N}$ has a significant effect on biomass production, $\mathrm{N}$ does reduce the time required to reach maximum production. Further, it seems unlikely that $50 \mathrm{Mg}$ removals of biomass every 5 y could be sustained without $\mathrm{N}$ additions. Kopp et al. [75] found that, with $\mathrm{N}$ additions of $336 \mathrm{kgN} \mathrm{ha}^{-1} \mathrm{y}^{-1}$, the cycle from cutting to harvest was reduced by one year in both poplar and willow. However, it is not clear that such extreme fertilizer additions are necessary to achieve this gain.

Figure 4. Yield responses of short-rotation poplar (a) and willow (b) to fertilization (upper) and precipitation (lower).

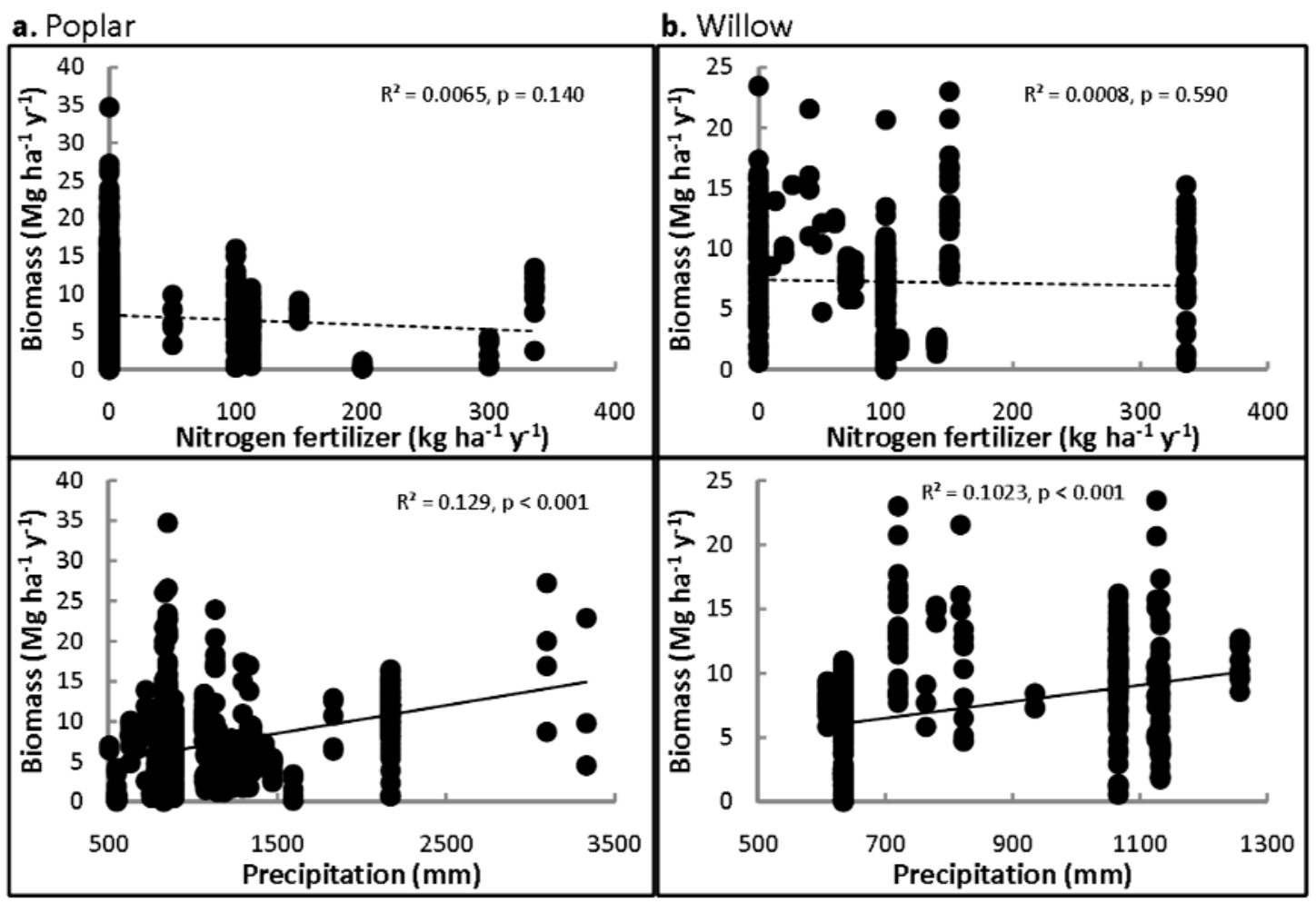

\subsubsection{Scenario 3: Model Simulation Results}

We simulated annual wood production and net $\mathrm{C}$ sequestration of poplar plantations in Mondovi, WI, USA, that were completely harvested at either 8 or 4 y intervals using the ED model [40-42]. ED has been validated against poplar production in multiple field sites in the Great Lake Region and also used to predict the annual growth of poplar for the 48 contiguous states of the US [44]. The simulation assumed no manipulations of water, N, or P. Annual wood production in the first harvesting cycle was comparable to the observed mean yield of two poplar clones collected in a field trial established in Mondovi, WI, USA [47]. If grown in $8 \mathrm{y}$ cycles, the model simulations of net $\mathrm{C}$ storage (including net 
biomass and soil accumulation) were negative for the first $20 \mathrm{y}$ and recovery occurred after about 3 harvesting cycles (Figure 5a). With a 4 y harvest cycle, the net $\mathrm{C}$ storage continued to decline over the $60 \mathrm{y}$ period (Figure 5b). In the longer harvesting cycle, the poplar plantation was a net sink of $\mathrm{C}$ after about $25 \mathrm{y}$, but in the shorter harvesting cycle, the poplar plantation was a net source of $\mathrm{C}$ to the atmosphere for the entire period of time tested. Carbon benefits will likely be increased with more recently bred high-productivity lines [72,77].

Figure 5. Simulated carbon storage in short-rotation poplar harvested at (a) 8-y intervals and (b) 4-y intervals in Mondovi, WI, USA.

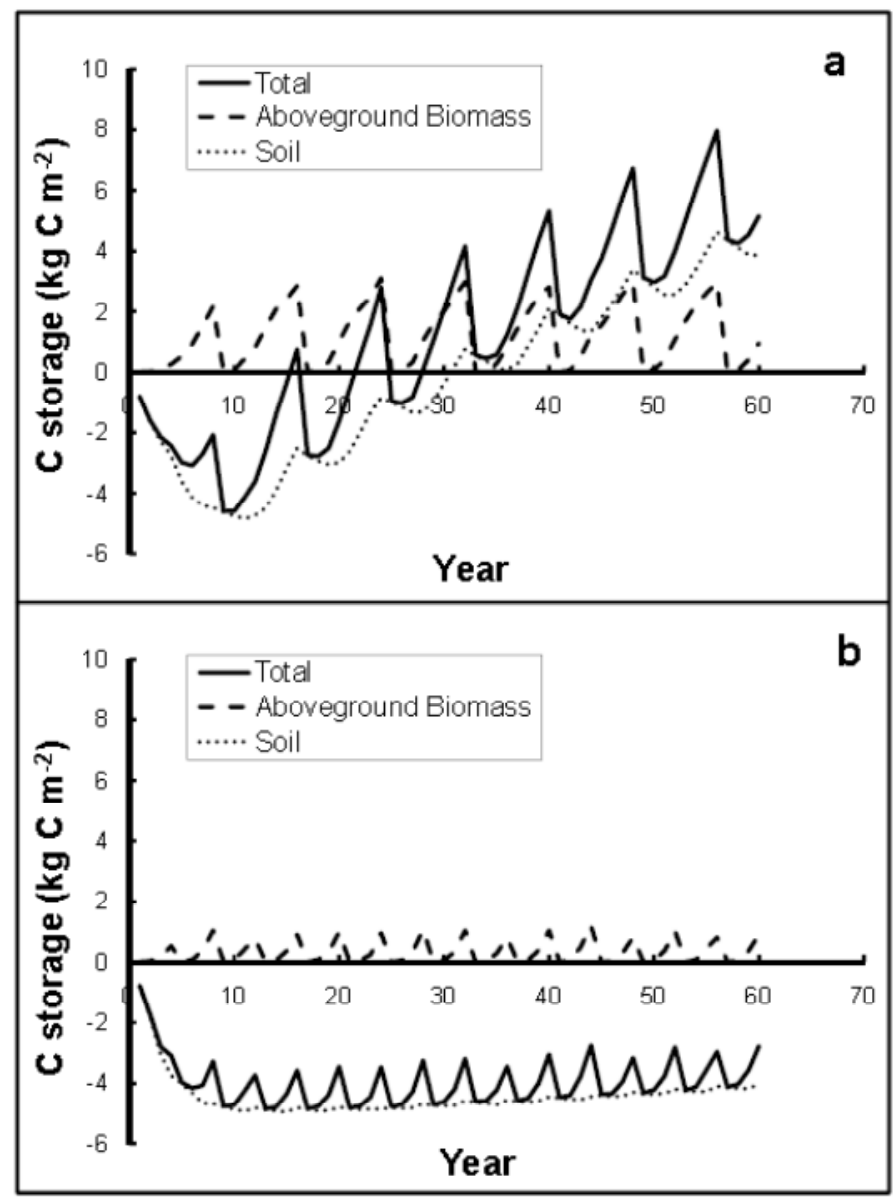

\subsection{Scenario 4: Residues}

Using data from the US Forest Service Timber Product Output reports, we calculated that eastern forests could supply over $118 \mathrm{Tg} \mathrm{y}^{-1}$ ( $\mathrm{Tg}=1$ million metric tons) of residual woody biomass (Table 1, [78]). More than a third of residues $\left(\sim 47 \mathrm{Tg} \mathrm{y}^{-1}\right)$ are considered forest residues, material left on-site following tree removal. This consists mainly of standing deadwood, felled branches and stumps. The cost of retrieval and transport of this material could however be prohibitive unless harvest practices are combined with roadside chipping and compacting [79]. The "practical" availability of such material is estimated by some to range from 40 to $60 \%$ (of forest residue) or 19 to $28 \mathrm{Tg} \mathrm{y}^{-1}$ given technical and cost constraints [78], while new technologies can recover $>60 \%[80,81]$. Other estimates are much more optimistic and anticipate 26 to $37 \mathrm{Tg} \mathrm{y}^{-1}$ of recoverable forest residues from only the 
southern region of the eastern US [31]. Despite costs, which depend on the residue type, transport distance, and end use, Gan and Smith [82] estimated that the economic output of forest residues can be $\$ 269 \mathrm{t}^{-1}$ if residue biomass is used for electricity generation. Residues from primary mills, including bark, sawdust and trimmings, comprise over $40 \%$ of the total residue biomass [80], and availability of residues depends on the amount that is left unused by timber mills. Improvements in mill efficiencies and use of residues in on-site power generation have contributed to a steady decline in residue generation [83]; less than $3 \%$ of mill residues $\left(\sim 1 \mathrm{Tg}^{-1}\right)$ are considered currently "unused."

Table 1. Eastern forest mill and urban residues (1000 dry $\left.\mathrm{Mg} \mathrm{y}^{-1}\right)$ [78].

\begin{tabular}{|c|c|c|c|c|c|c|}
\hline \multirow[t]{2}{*}{ State } & \multirow{2}{*}{$\begin{array}{c}\text { Forest } \\
\text { Residues }\end{array}$} & \multicolumn{2}{|c|}{$\begin{array}{c}\text { Primary Mill } \\
\text { Residues }\end{array}$} & \multirow{2}{*}{$\begin{array}{l}\text { Secondary Mill } \\
\text { Residues }\end{array}$} & \multirow{2}{*}{$\begin{array}{c}\text { Urban } \\
\text { Residues }\end{array}$} & \multirow[t]{2}{*}{ Total } \\
\hline & & Total & Unused & & & \\
\hline \multicolumn{7}{|l|}{ Northeast Region } \\
\hline Connecticut & 78 & 75 & 0 & 24 & 376 & 553 \\
\hline Delaware & 51 & 14 & 0 & 8 & 85 & 158 \\
\hline District of Columbia & 0 & 0 & 0 & 0 & 56 & 56 \\
\hline Maine & 2,890 & 421 & 35 & 15 & 133 & 3,459 \\
\hline Maryland & 263 & 113 & 0 & 33 & 624 & 1,033 \\
\hline Massachusetts & 89 & 113 & 0 & 52 & 687 & 941 \\
\hline New Hampshire & 986 & 925 & 19 & 18 & 126 & 2,055 \\
\hline New Jersey & 29 & 17 & 0 & 58 & 894 & 998 \\
\hline New York & 1,111 & 1,063 & 24 & 119 & 2,041 & 4,334 \\
\hline Pennsylvania & 1,679 & 1,358 & 144 & 127 & 1,238 & 4,402 \\
\hline Rhode Island & 8 & 21 & 0 & 6 & 109 & 144 \\
\hline Vermont & 496 & 103 & 0 & 9 & 65 & 673 \\
\hline West Virginia & 1,347 & 807 & 114 & 15 & 184 & 2,353 \\
\hline Regional Total & 9,027 & 5,030 & 336 & 484 & 6,618 & 21,159 \\
\hline Percent of Total US & $16 \%$ & $7 \%$ & $21 \%$ & $19 \%$ & $21 \%$ & $13 \%$ \\
\hline \multicolumn{7}{|l|}{ Great Lakes Region } \\
\hline Illinois * & 664 & 233 & 14 & 96 & 1,337 & 2,330 \\
\hline Indiana * & 863 & 574 & 26 & 71 & 715 & 2,223 \\
\hline Michigan & 1,275 & 1,314 & 41 & 86 & 1,196 & 3,871 \\
\hline Minnesota & 2,242 & 985 & 65 & 59 & 496 & 3,782 \\
\hline Missouri * & 1,840 & 1,036 & 130 & 69 & 613 & 3,558 \\
\hline Ohio & 796 & 786 & 18 & 124 & 1,272 & 2,978 \\
\hline Wisconsin & 2,011 & 1,621 & 30 & 69 & 548 & 4,249 \\
\hline Regional Total & 9,691 & 6,549 & 324 & 574 & 6,177 & 22,991 \\
\hline Percent of Total US & $17 \%$ & $8 \%$ & $20 \%$ & $22 \%$ & $20 \%$ & $14 \%$ \\
\hline \multicolumn{7}{|l|}{ Southeast Region } \\
\hline Alabama & 2,555 & 5,857 & 10 & 57 & 483 & 8,952 \\
\hline Arkansas & 2,874 & 3,623 & 131 & 32 & 314 & 6,843 \\
\hline Florida & 1,778 & 1,901 & 4 & 130 & 1,678 & 5,487 \\
\hline Georgia & 3,556 & 7,231 & 66 & 97 & 924 & 11,808 \\
\hline Kentucky & 2,055 & 1,433 & 77 & 52 & 454 & 3,994 \\
\hline
\end{tabular}


Table 1. Cont.

\begin{tabular}{|c|c|c|c|c|c|c|}
\hline \multirow[t]{2}{*}{ State } & \multirow{2}{*}{$\begin{array}{c}\text { Forest } \\
\text { Residues }\end{array}$} & \multicolumn{2}{|c|}{$\begin{array}{c}\text { Primary Mill } \\
\text { Residues }\end{array}$} & \multirow{2}{*}{$\begin{array}{l}\text { Secondary Mill } \\
\text { Residues }\end{array}$} & \multirow{2}{*}{\multicolumn{2}{|c|}{$\begin{array}{c}\text { Urban } \\
\text { Residues }\end{array}$}} \\
\hline & & Total & Unused & & & \\
\hline Louisiana & 3,384 & 3,577 & 14 & 33 & 474 & 7,468 \\
\hline Mississippi & 3,825 & 4,548 & 79 & 33 & 307 & 8,713 \\
\hline North Carolina & 2,995 & 3,900 & 14 & 115 & 833 & 7,843 \\
\hline South Carolina & 1,733 & 2,468 & 9 & 38 & 467 & 4,706 \\
\hline Tennessee & 1,319 & 1,557 & 153 & 75 & 614 & 3,565 \\
\hline Virginia & 2,403 & 2,147 & 66 & 62 & 813 & 5,425 \\
\hline Regional Total & 28,477 & 38,242 & 623 & 724 & 7,361 & 74,804 \\
\hline Percent of Total US & $50 \%$ & $50 \%$ & $39 \%$ & $28 \%$ & $24 \%$ & $44 \%$ \\
\hline Total Eastern US & 47,195 & 49,821 & 1,283 & 1,782 & 20,156 & 118,954 \\
\hline Total US & 56,612 & 77,125 & 1,606 & 2,615 & 30,902 & 168,860 \\
\hline Percent of Total & $83 \%$ & $65 \%$ & $80 \%$ & $68 \%$ & $65 \%$ & $70 \%$ \\
\hline
\end{tabular}

* Not included or only partially included in the eastern forest biome defined by WWF and delineated on the map in Figure 6.

Urban woody biomass from tree trimmings, land development, and management of urban-forest boundaries contribute another possible $20 \mathrm{Tg} \mathrm{y}^{-1}$ of biomass from the eastern US. In 2002, $62.5 \mathrm{Tg}$ of wood biomass was generated from construction, demolition, and landscaping wastes across the nation [33]. A portion of this biomass $(9.7 \mathrm{Tg})$ was recovered, demonstrating the feasibility of collection. Approximately half of the urban residue generated was left unused [33].

The role of urban residues in the portfolio of woody biomass for energy is possibly the least explored because this waste stream is often combined with estimates of organic municipal solid waste. The importance of this residue source is likely to continue to grow with population and urbanization. For cellulosic biofuel production, the major challenges will be identifying urban locations where sufficient residue is available for a commercially viable operation. Given the diversity of residue composition, it is less likely to be a suitable feedstock for biochemical production of ethanol, but would be more suited for combustion to provide heat and power (thermochemical conversion to fuels).

Residue production depends on management decisions that directly affect primary (non-residue) resources. Drivers that affect current biomass harvesting for timber, pulpwood and related mill activity will in turn affect the amount of mill residues that could be used for bioenergy. Increased demand for residues may result in higher prices and displacement of current alternate uses [84]; however current policy such as the revised Renewable Fuel Standard [1] will inhibit such market interactions.

Extraction of tree limbs and tops is not uncommon in timber operations, but the potential removal of small-diameter trees, downed logs, stumps, shrubs, litter/duff is uncertain because methods for and the impacts of these removals vary [20,21]. Foliage and branches contain higher concentrations of essential nutrients than tree boles and thus increased extraction of non-bole biomass may lead to a reduction in soil fertility $[21,85,86]$. Nutrient limitation is likely to be a greater concern in the southeast, where lands have been managed more intensively, and both $\mathrm{N}$ and $\mathrm{P}$ limitation has been documented in the forest (reviewed above). Nitrogen is often not limiting in the northeast and other 
nutrients deplete slowly. Analyses of nutrient budgets in the eastern United States have suggested that calcium is the nutrient most likely to experience gradual but long-term depletion [21].

Effects on soil C and fertility appear to be highly site-specific and subject to management practices. For pine forests, several studies comparing stem-only, whole tree or complete tree harvests (removing slash and some forest floor components) had mixed results [87,88]. While whole tree harvesting and removal of residues may negatively impact $\mathrm{C}$ pools at some sites, starting soil conditions, timing of harvest, fertilization, understory competition, and tempered herbicide treatments can improve soil $\mathrm{C}[87,88]$.

\subsection{Abandoned Lands}

We estimated the area of abandoned agricultural land that is not currently in forest or urban development but is part of the eastern forest biome zone in the US to be between 10.8 and 20.4 Mha based on [22]. This is 4 and $8 \%$ of all land in the eastern US forest biome, respectively. In the last $15 \mathrm{y}$ alone, 30.2 Mha of agricultural land was abandoned in the region but a significant portion of this land has been consumed by urban developments, leaving $~ 16.6$ Mha of non-forested abandoned lands. To place this in context, the largest single crop in the US, maize, currently occupies 40 Mha of the contiguous 48 states. A greater proportion of the land abandonment occurred in the southeast (8.83 Mha) relative to the northeast (3.84 Mha) and the Great Lakes (3.94 Mha) (Figure 6). The northeast region experienced greater agricultural abandonment in the 1800s and earlier in the 1900s. As a result, much of this area is now comprised of mature forests ( $>100 \mathrm{y}$ old forest) with high species diversity, ecosystem services and recreational value. The exceptions to this are large areas of southwestern New York and eastern Maryland that have transitioned out of agriculture more recently.

Figure 6. Maximum estimates of abandoned agricultural land in the US that is not currently in forest or urban development, increasing from red to blue (adapted from [22]). The eastern forest biome that was analyzed in this study is outlined in black.

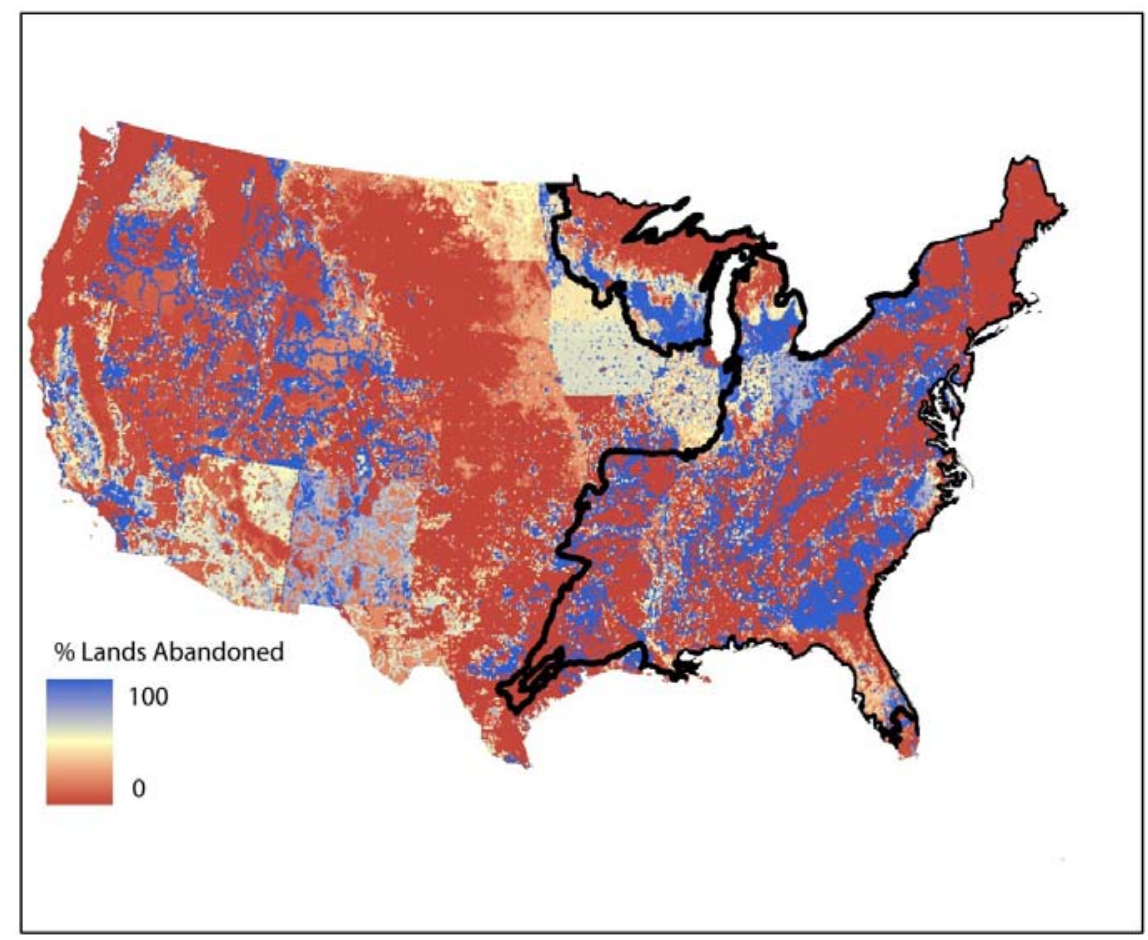




\subsection{Discussion}

If all abandoned agricultural land and unmanaged forests were harvested according to the practices reviewed here, we estimate that $191 \mathrm{Tg}$ (million metric tons) of wood biomass could be collected annually for bioenergy, but this management would be unsustainable due to a loss of $-1.7 \mathrm{Tg} \mathrm{C} \mathrm{y}^{-1}$ to the atmosphere (Table 2). By reducing the amount of land managed for pine plantations to $17 \%$ of abandoned land in the southeast (simulating a landscape-level partial harvest plan), we estimated that $\sim 176 \mathrm{Tg} \mathrm{y}^{-1}$ of wood biomass ( $\sim 330,000 \mathrm{GWh}$ electricity or $\sim 16$ billion gallons liquid fuel) could be harvested sustainably in the eastern US for bioenergy with an annual $\mathrm{C}$ sequestration of $8 \mathrm{Tg} \mathrm{C}^{-1}$ (Table 2) over a $60 \mathrm{y}$ time horizon. This could displace $\sim 63 \mathrm{Tg} \mathrm{C} \mathrm{y}^{-1}$ from fossil fuel emissions if used for heat and power generation or $\sim 19 \mathrm{Tg} \mathrm{C} \mathrm{y}^{-1}$ if used to produce ethanol. These estimates should be viewed as approximations and are subject to a number of assumptions and will vary according to the wide range of managements, climate conditions and soils that exist across the large regions simulated. Five sources of biomass are included in this estimate: short-rotation woody crops in the Great Lakes regions, pine plantations in the southeast, partial harvests in the northeast, woody residues, and partial harvest of currently unmanaged and unreserved forests in all three regions.

Table 2. Estimates of land and potential production of woody biomass for bioenergy.

\begin{tabular}{|c|c|c|c|c|c|}
\hline & Great Lakes & Northeast & Southeast & - & $\begin{array}{c}\text { Eastern US } \\
\text { Total } \\
\end{array}$ \\
\hline $\begin{array}{l}\text { Unmanaged and unreserved } \\
\text { forestland * (ha) }\end{array}$ & 383,000 & 323,000 & $1,281,000$ & - & $1,987,000$ \\
\hline $\begin{array}{l}\text { Potential biomass from partial } \\
\text { harvest annually ** }\left(\mathrm{Mg} \mathrm{ha}^{-1} \mathrm{y}^{-1}\right)\end{array}$ & 434,067 & 366,067 & $1,451,800$ & - & $2,251,933$ \\
\hline Abandoned cropland (ha) & $3,830,000$ & $3,100,000$ & $8,810,000$ & - & $15,740,000$ \\
\hline Abandoned pasture (ha) & 110,000 & 740,000 & 20,000 & - & 870,000 \\
\hline $\begin{array}{l}\text { Total abandoned agricultural land } \\
\text { (ha) }\end{array}$ & $3,940,000$ & $3,840,000$ & $8,830,000$ & - & $16,610,000$ \\
\hline $\begin{array}{l}\text { Regional harvesting practice likely } \\
\text { on abandoned land }\end{array}$ & $\begin{array}{l}\text { Short } \\
\text { Rotation } \\
\text { Woody }\end{array}$ & $\begin{array}{l}\text { Partial } \\
\text { harvest }\end{array}$ & $\begin{array}{c}\text { Pine } \\
\text { plantation }\end{array}$ & - & - \\
\hline Establishment time (y) & 8 & 80 & 12 to 20 & - & - \\
\hline $\begin{array}{l}\text { Biomass available annually after } \\
\text { establishment }\left(\mathrm{Mg} \mathrm{y}^{-1}\right)\end{array}$ & 8.15 & 1.13 & 12.40 & - & - \\
\hline $\begin{array}{l}\text { Total potential biomass cultivated } \\
\text { on abandoned agricultural lands } \\
\left(\mathrm{Mg} \mathrm{y}^{-1}\right)\end{array}$ & $32,111,000$ & $4,352,000$ & $109,492,000$ & - & $145,955,000$ \\
\hline $\begin{array}{l}\text { Total potential biomass with only } \\
\text { partial plantation management } * * * \\
\left(\mathrm{Mg} \mathrm{y}^{-1}\right)\end{array}$ & - & - & - & $18,613,640$ & $55,076,640$ \\
\hline $\begin{array}{l}\text { Carbon sequestration rate } * * * * \\
\left(\mathrm{Mg} \mathrm{C} \mathrm{ha}^{-1} \mathrm{y}^{-1}\right)\end{array}$ & 0.0144 & 0.542 & -0.554 & - & 0.0024 \\
\hline
\end{tabular}


Table 2. Cont.

\begin{tabular}{lccccc}
\hline & Great Lakes & Northeast & Southeast & $-\begin{array}{c}\text { Eastern US } \\
\text { Total }\end{array}$ \\
\hline $\begin{array}{l}\text { Total Carbon sequestered } \\
\left(\mathrm{Mg} \mathrm{C} \mathrm{y}^{-1}\right)\end{array}$ & 264,322 & $2,256,346$ & $-4,197,518$ & - & $-1,676,850$ \\
$\begin{array}{l}\text { Total Carbon sequestered with only } \\
\text { partial plantation management } \\
\left(\mathrm{Mg} \mathrm{C} \mathrm{y}^{-1}\right)\end{array}$ & - & - & - & $5,480,162$ & $8,000,830$ \\
\hline Residues $(\mathrm{Mg})$ & & & & & \\
\hline $\begin{array}{l}\text { Total potential biomass available } \\
\text { annually***** (Mg) }\end{array}$ & $55,536,067$ & $25,877,067$ & $94,869,440$ & - & $176,282,573$ \\
$\begin{array}{l}\text { Liquid fuel equivalent (billion } \\
\text { gallons ethanol) }\end{array}$ & 5.11 & 2.38 & 8.73 & - & 16.22 \\
$\begin{array}{l}\text { Power from combustion equivalent } \\
(\mathrm{GWh})\end{array}$ & 103,852 & 48,390 & 177,406 & - & 329,648 \\
\hline
\end{tabular}

* Based on [78]; ** Calculated based on partial harvest biomass estimates reviewed here that are multiplied by the amount of unmanaged and unreserved forestland; *** Partial plantation management assumes that at any given time only $17 \%$ of the available abandoned lands are managed as plantations and harvested after $15 \mathrm{y} ; * * * *$ Based on literature reviewed in this paper; $* * * * *$ Sum of numbers highlighted with bold text in each region.

In the Great Lakes region, there is a potential to harvest $32 \mathrm{Tg} \mathrm{y}^{-1}$ from short rotation woody crops planted on abandoned agricultural land and $0.43 \mathrm{Tg} \mathrm{y}^{-1}$ of biomass from unmanaged and unreserved forestland while maintaining terrestrial $\mathrm{C}$ sequestration (Table 2). This assumes that short-rotation woody crops could be cultivated on abandoned lands with 8 y rotations between harvests. In the southeast, $109 \mathrm{Tg} \mathrm{y}^{-1}$ could be cultivated in pine plantations on abandoned lands, but this would result in a gradual decline in terrestrial $\mathrm{C}$ stocks (Table 2). Partial harvest of currently unmanaged and unreserved forestland in southeast could yield $1.45 \mathrm{Tg} \mathrm{y}^{-1}$ of biomass. Using only partial harvests in the northeast region where much of the forest is mature and there is less recently abandoned land, it would be possible to harvest $4.35 \mathrm{Tg} \mathrm{y}^{-1}$ (Table 2) while maintaining forest $\mathrm{C}$ stocks and habitat, but only $0.36 \mathrm{Tg}$ would be immediately available because time must be allowed for forest regeneration on the abandoned land parcels. Finally, woody residues can yield $119 \mathrm{Tg} \mathrm{y}^{-1}$ across all three regions (Tables 1 and 2).

Literature review and temporally dynamic simulations of woody feedstock production clearly demonstrate differences among the four harvesting scenarios in their capacity to produce bioenergy feedstocks, to offset $\mathrm{CO}_{2}$ emissions, and consequently to address climate change mitigation. Low intensity biomass management of secondary hardwood forests, via partial harvests (10-17\% removals), results in greater $\mathrm{C}$ sequestration relative to more intensive harvests ( $>34 \%$ removals) and $\mathrm{C}$ uptake is maintained over both the short-term (11 y) and long-term (60 y) time periods that were analyzed (Figure 1). Plantation management and short rotation woody crops result in gains or losses of $\mathrm{C}$ to the atmosphere depending on the harvest rotation interval and the duration of the practice. Pine plantation management results in a net sink of $\mathrm{C}$ in the short-term $(11 \mathrm{y})$, but this practice becomes a net source of $\mathrm{C}$ to the atmosphere over the long-term $(60 \mathrm{y})$. Short rotation woody crops are a net source of $\mathrm{C}$ to the atmosphere in the short-term but this practice becomes a net sink of $\mathrm{C}$ over time with $8 \mathrm{y}$ harvest 
intervals (Figure 5). The initial soil disturbance for planting results in a release of $\mathrm{C}$, but long-term growth eventually exceeds respiratory losses.

Woody residues represent a large proportion of the available biomass feedstock $(67 \%)$ in the eastern US. The majority of woody residues from eastern forests are produced through active logging and milling activity in the southeast. In this region, eleven states produce roughly half the woody residue material in the US. This is the only region in the U.S. with projected continued growth in timber harvesting [32]. International competition, especially in the pulp market, has depressed some mill activity but growing markets for bioenergy pellets as a result of the E.U. Renewable Energy Directive has stimulated growth, as has the Community Wood Energy Program of the 2008 Farm Bill (although to a lesser extent). In contrast, the availability of wood and wood residues in the northeastern US appears to be limited by social factors, mainly associated with landowner attitudes which tend toward minimal management of secondary forests and the lower economic activity in the forest sector relative to the southeast [5]. If partial harvest or short rotation woody crops were adopted in the northeast and Great Lakes regions, some additional woody residues would be generated that are not included in the estimates provided here.

\subsubsection{Sustainability Targets for Bioenergy}

In bioenergy management, there are four kinds of sustainability that must be considered: climate change mitigation, environmental sustainability, economic sustainability, and energy security. Inevitably there are tradeoffs that do not allow all four aspects of sustainability to be maximized simultaneously, but we will briefly discuss how our results relate to each one. Results from this study directly inform objectives related to climate change mitigation and environmental sustainability (in $\mathrm{C}$ storage, 1 unit $\mathrm{C}=3.67$ units $\mathrm{CO}_{2}$ ). Analysis of harvest costs and legislation are required to thoroughly address economic and energy security sustainability. While such analysis is beyond the scope of this study, we will provide brief examples of how economic and policy instruments can affect the sustainability of biomass production in the forested region of the Eastern US.

Although terrestrial $\mathrm{C}$ sequestration can be a large sink, climate change mitigation requires more holistic strategies that are not limited in scope to simple manipulations of $\mathrm{C}$. Nitrogen and $\mathrm{P}$ management, for example, can have important implications for not only production and $\mathrm{C}$ sequestration but also for GHG emissions associated with manufacturing fertilizer. Application of fertilizers could boost $\mathrm{C}$ sequestration in the plantation system for example (Figure 3), but can also lead to large GHG fluxes. Based on the rates of $\mathrm{N}$ applied to plantations and cropping systems reviewed here $\left(36-195 \mathrm{kgN} \mathrm{ha}^{-1} \mathrm{y}^{-1}\right)$, the additional GHG emission associated with $\mathrm{N}$ fertilizer manufacturing would be between 31 and $291 \mathrm{~kg} \mathrm{CO}_{2 \text { eq }} \mathrm{ha}^{-1}[89,90]$. Based on the range of $\mathrm{P}$ applications analyzed here $\left(8-112 \mathrm{kgP} \mathrm{ha}^{-1} \mathrm{y}^{-1}\right)$, the additional GHG flux associated with P fertilizer manufacturing would be between 5 and $66 \mathrm{~kg} \mathrm{CO}_{2 \mathrm{eq}} \mathrm{ha}^{-1}$ [90]. Over a 60 -year period, the combined application of $\mathrm{N}$ and $\mathrm{P}$ could result in an emission that is up to $14 \mathrm{Mg} \mathrm{CO}_{2 \mathrm{eq}}$ ha $^{-1}$ greater than a management system with no input requirements (i.e., partial harvest). This GHG emission would be in addition to the terrestrial $\mathrm{C}$ fluxes we have described (e.g., Figures 3 and 5) and reported in Table 2. This estimate does not include emissions of $\mathrm{N}_{2} \mathrm{O}$ that would occur at the time of fertilizer application, another significant source of GHG in managed landscapes. 
In addition to $\mathrm{C}$ sequestration and GHG mitigation, environmental sustainability also depends on maintaining or enhancing biodiversity, ecosystem function, and water quality. Low intensity partial harvests, at a site-level or landscape-level, by definition allow the retention of aboveground biomass (e.g., $83 \%$ biomass remains standing after a 17\% harvest). Therefore, properly designed harvest regimes may maintain the inherent diversity of forest plant communities that mediate biogeochemical cycling and provide habitat for vertebrate and invertebrate wildlife of multiple trophic levels. Nationwide, BMPs often invoke low intensity partial harvests rather than intensive plantations or even-age management at the landscape level to accomplish environmental benefits, primarily maintenance of water quality [27]. However, landscape-level patch cutting on a small percentage of land while maintaining a mature forest across the majority of a landscape may be sustainable because this practice limits the number of entry points for machinery that can lead to increased soil disturbance and incur additional costs. Such management requires long-term planning if the goal is to maintain a continuous biomass supply.

Since long-term economic sustainability depends on the biological potential of a managed forest or plantation system, it is important to weigh short-term economic gains against both the biological and economic potential of a forest in the long-term. To do this, economic analyses should distinguish total standing biomass from incremental biomass changes in a forest to reconcile short-term goals with long-term sustainability. Even though a lower amount of biomass per unit area is harvested in low-intensity partial harvests than from clear-cut plantations, the sustainability of production and the value per unit product are greater than high-intensity timbering (Figure 7). The harvest of many small diameter stems is more expensive per unit mass than the harvest of larger stems that yield the same biomass in fewer stems [91]. If one assumes a landscape level approach to management, small areas of the landscape might be harvested intensively but large-diameter trees can be cultivated by staggering the location and increasing the interval of harvest at a single location to $80+$ years.

Figure 7. Mean biomass harvested with different managements (a) and estimated profit per $\mathrm{Mg}$ biomass with an assumed selling price of $\$ 50 \mathrm{Mg}^{-1}$, (b) in different forest management scenarios.

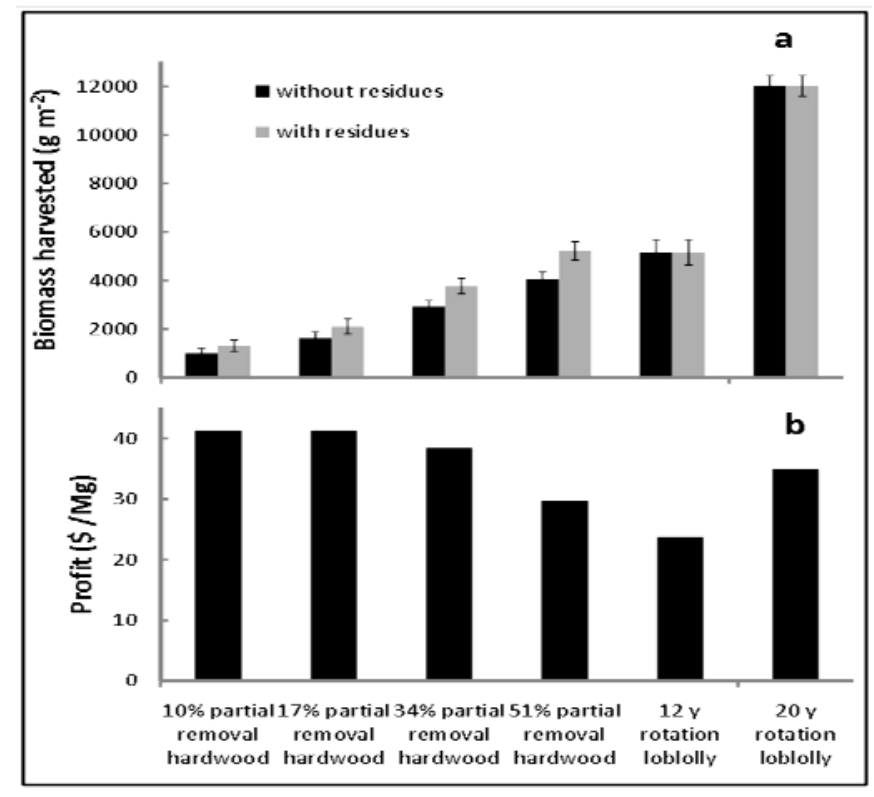


Increasing interest in bioenergy is expanding markets for forest materials that have historically had little commercial value, such as small-diameter trees and logging residues [17,21,81]. Some of the forest-derived material that could be used for bioenergy already is being extracted from the forest (e.g., living or dead trees removed for fuel reduction or forest health); bioenergetic utilization of this feedstock is limited primarily by transportation costs and processing infrastructure [81]. To maintain ecological integrity and ensure sustainability in eastern forests, some proportion of the available biomass in any given stand should remain on site, and this residual material should consist of multiple biomass categories (e.g., large dead wood, small-diameter trees, logging residues). However, precise quantities are mostly unknown and are likely to be highly site-specific [20,21]. Thus we recommend careful consideration of the tradeoffs between economic benefits and local ecology when managing residues.

The estimated $176 \mathrm{Tg} \mathrm{y}^{-1}$ of biomass that could be produced relatively sustainably from woody feedstocks in the eastern US is enough to generate $\sim 16$ billion gallons of ethanol annually. This is equivalent to $4 \%$ of liquid fuel consumption in the US in 2009 [92]. The degree to which energy security objectives can be met by harvesting wood resources in the eastern US depends on the amount of land that is available to provide biomass. Abandoned lands in the eastern US total anywhere from 10.8 to 20.4 Mha depending on the degree to which abandonment of crops was offset by transitions to pasture or vice versa. For each scenario that was discussed here, we can only roughly estimate the potential biomass production from abandoned lands.

\subsubsection{Payback Times}

A payback time is defined as the time it takes to recuperate a lost pool of $\mathrm{C}$ plus the loss in the continued stimulation of $\mathrm{C}$ sequestration that may have occurred by displacing the baseline condition $[93,94]$. If a new management practice is to be introduced for biomass production, then the initial conditions of forestlands must be considered. The initial conditions define the trajectory of $\mathrm{C}$ storage and allow for a more accurate estimate of payback times. All of the scenarios modeled in the results were analyzed without accounting for differences in land use practices prior to agricultural abandonment. The exception to this is the partial harvesting scenario, which assumes a mature closed-canopy forest prior to time zero.

Payback times for an initial disturbance or land use change are handled differently in different disciplines [95,96]. One reason for disagreement about the method for calculating payback times associated with bioenergy agriculture is that the conversion efficiency of the bioenergy products (energy per unit C) is not equal to the conversion efficiency of the fossil fuel technology that is being replaced. Displacement of fossil fuels can reduce or eliminate payback times [97]. With a displacement of $4 \%$ of transportation fuels in the US, the payback would be reduced by $25 \mathrm{Tg} \mathrm{C}$ annually (emissions that would no longer be released from fossil fuels). Among the harvesting practices reviewed in this study, pine plantations are the most likely to result in $\mathrm{C}$ emissions. With pine plantations on abandoned lands in the southeast included as a source of biomass in the eastern US, we estimated that $\mathrm{C}$ would be emitted to the atmosphere at a rate of $1.7 \mathrm{Tg}$ of $\mathrm{C} \mathrm{y}^{-1}$. Although we conclude this is unsustainable relative to alternative practices, it should be noted that emissions from intensive forest management for biomass are an order of magnitude less than the emissions currently produced from fossil fuel use. 


\subsubsection{Relevance to Life-Cycle Analysis}

Our analysis describes only the terrestrial fluxes that would be inputs to a life-cycle analysis of bioenergy production from wood resources. There are many other components that ultimately must be considered when evaluating the production chain associated with each scenario [95]. Upstream of resource production, one would consider land use change, machinery, land preparation, fertilizer and equipment manufacturing. Downstream, one must consider co-products, fuel conversion processes, transportation, distribution, and infrastructure costs. The focus of this study was limited to terrestrial ecosystem fluxes of GHG.

\section{Conclusions}

To optimize the production potential of feedstock sources, there is a choice between management intensification and extensification [98]. In the case of biomass harvests from forestlands in the eastern US, intensification through site-level plantation management or short-rotation woody cropping reduces the land footprint for a given amount of resource produced, but increases the input requirements and environmental cost. More extensive management is required to produce the same amount of biomass through partial harvests or residue collection, increasing the land footprint for resource production, but reducing inputs and environmental costs. Ultimately, we need feedstock solutions that optimize biomass production, reduce inputs, and lower environmental and economic risks. Our analysis suggests that $\sim 176 \mathrm{Tg}$ of wood biomass could be harvested from eastern US forestlands without diverting current wood products, damaging habitat, or reducing terrestrial $\mathrm{C}$ sinks.

\section{Acknowledgments}

Special thanks to Christine Goodale for valuable input about nutrient use in eastern US forests. We also thank Michael Kampwerth and Jeanie Rhoads for assistance with literature reviews. This work was supported by funds from the Energy Biosciences Institute and is the outcome of a workshop held in San Francisco, CA, USA on 10 December 2010.

\section{Conflict of Interest}

The authors declare no conflict of interest.

\section{References}

1. EPA. Regulation of fuels and fuel additives: 2011 Renewable fuel standards. Fed. Regist. 2011, 75, 76790-76830.

2. USDA. Notice of funds availability for the collection, harvest, storage, and transportation of eligible material. Fed. Regist. 2009, 74, 27767-27772.

3. Houghton, R.A. Revised estimates of the annual net flux of carbon to the atmosphere from changes in land use and land management 1850-2000. Tellus 2003, 55, 378-390. 
4. Heath, L.S.; Maltby, V.; Miner, R.; Skog, K.E.; Smith, J.E.; Unwin, J.; Upton, B. Greenhouse gas and carbon profile of the U.S. forest products industry value chain. Environ. Sci. Technol. 2010, 44, 3999-4005.

5. Butler, B.; Ma, Z.; Kittredge, D.; Catanzaro, P. Social versus biophysical availability of wood in the northern United States. North J. Appl. For. 2010, 27, 151-159.

6. Nave, L.E.; Vance, E.D.; Swanston, C.W.; Curtis, P.S. Harvest impacts on soil carbon storage in temperate forests. For. Ecol. Manag. 2010, 259, 857-866.

7. Turner, D.P.; Koerper, G.J. Carbon sequestration by forests of the United States. Current status and projections to the year 2040. Tellus 1995, 47, 232-239.

8. Zan, C.S.; Fyles, J.W.; Girouard, P.; Samson, R.A. Carbon sequestration in perennial bioenergy, annual corn and uncultivated systems in southern Quebec. Agric. Ecosyst. Environ. 2001, 86, $135-144$.

9. Lal, R. Soil carbon sequestration impacts on global climate change and food security. Science 2004, 304, 1623-1627.

10. Anderson-Teixeira, K.J.; Davis, S.C.; Masters, M.D.; DeLucia, E.H. Changes in soil organic carbon under biofuel crops. Glob. Change Biol. Bioenergy 2009, 1, 75-96.

11. Richter, D.D.; Markewitz, D.; Trumbore, S.E.; Wells, C.G. Rapid accumulation and turnover of soil carbon in a re-establishing forest. Nature 1999, 400, 56-58.

12. Schlesinger, W.H. Evidence from chronosequence studies for a low carbon-storage potential of soils. Nature 1990, 348, 232-234.

13. Schlesinger, W.H.; Lichter, J. Limited carbon storage in soil and liiter of experimental forest plots under increased atmospheric $\mathrm{CO}_{2}$. Nature 2001, 411, 466-469.

14. Davis, S.C.; Hessl, A.E.; Scott, C.J.; Adams, M.B.; Thomas, R.B. Forest carbon sequestration changes in response to timber harvest. For. Ecol. Manag. 2009, 258, 2101-2109.

15. Nunery, J.S.; Keeton, W.S. Forest carbon storage in the northeastern United States: Net effects of harvesting frequency, post-harvest retention, and wood products. For. Ecol. Manag. 2010, 259, 1363-1375.

16. Sartori, F.; Lal, R.; Ebinger, M.H.; Parrish, D.J. Potential soil carbon sequestration and $\mathrm{CO}_{2}$ offset by dedicated energy crops in the USA. Crit. Rev. Plant Sci. 2006, 25, 441-472.

17. Malmsheimer, R.W.; Heffernan, P.; Brink, S.; Crandall, D.; Deneke, F.; Galik, C.; Gee, E.; Helms, J.A.; McClure, N.; Mortimer, M.; Ruddell, S.; Smith, M.; Stewart, J. Preventing GHG emissions through biomass substitution. J. For. 2008, 106, 136-140.

18. Seidl, R.; Rammer, W.; Jager, D.; Currie, W.; Lexer, M. Assessing trade-offs between carbon sequestration and timber production within a framework of multi-purpose forestry in Austria. For. Ecol. Manag. 2007, 248, 64-79.

19. Van Deusen, P. Carbon sequestration potential of forest land: Management for products and bioenergy versus preservation. Biomass Bioenergy 2010, 34, 1687-1694.

20. Evans, A.M.; Perschel, R.T.; Kittler, B.A. Revised Assessment of Biomass Harvesting and Retention Guidelines; Forest Guild: Santa Fe, NM, USA, 2010.

21. Janowiak, M.K.; Webster, C.R. Promoting ecological sustainability in woody biomass harvesting. J. For. 2010, 108, 16-23. 
22. Campbell, J.E.; Lobell, D.B.; Genova, R.C.; Field, C.B. The global potential of bioenergy on abandoned agriculture lands. Environ. Sci. Technol. 2008, 42, 5791-5794.

23. Garten, C.T.; Wullschleger, S.D. Soil carbon inventories under a bioenergy crop (switchgrass): Measurement limitations. J. Environ. Qual. 1999, 28, 1359-1365.

24. Garten, C.T.; Wullschleger, S.D. Soil carbon dynamics beneath switchgrass as indicated by stable isotope analysis. J. Environ. Qual. 2000, 29, 645-653.

25. Hansen, E.A. Soil carbon sequestration beneath hybrid poplar plantations in the north central United States. Biomass. Bioenerg. 1993, 5, 431-436.

26. Buchholz, T.; Canham, C.D.; Hamburg, S.P. Forest Biomass and Bioenergy: Opportunites and Constraints in the Northeastern United States; Cary Institute of Ecosystem Studies: Millbrook, NY, USA, 2011.

27. Manomet Center for Conservation Sciences. Massachusetts Biomass Sustainability and Carbon Policy Study: Report to the Commonwealth of Massachusetts Department of Energy Resources. In Natural Capital Initiative at Manomet Report; Walker, T., Ed.; Report NCI-2010-03; Manomet Center for Conservation Sciences: Brunswick, ME, USA, 2010.

28. Xiao, J.; Zhuang, Q.; Law, B.E.; Baldocchi, D.D.; Chen, J. Assessing net ecosystem carbon exchange of U.S. terrestrial ecosystems by integrating eddy covariance flux measurements and satellite observations. Agric. For. Meteorol. 2011, 151, 60-69.

29. Schuler, T.M. Fifty years of partial harvesting in a mixed mesophytic forest: Composition and productivity. Can. J. For. Res. 2004, 34, 985-997.

30. McNulty, S.G.; Vose, J.M.; Swank, W.T. Loblolly pine hydrology and productivity across the southern United States. For. Ecol. Manag. 1996, 86, 241-251.

31. Conner, R.C.; Johnson, T.G. Estimates of Biomass in Logging Residue and Standing Residual Inventory Following Tree-Harvest Activity on Timberland Acres in the Southern Region; Department of Agriculture Forest Service, Southern Research Station: Asheville, NC, USA, 2011; p. 25.

32. Gan, J.; Smith, C. Availability of logging residues and potential for electricity production and carbon displacement in the USA. Biomass Bioenergy 2006, 30, 1011-1020.

33. McKeever, D.B. Inventories of Woody Residues and Solid Wood Waste in the United States, 2002. In Proceeding of The Ninth International Conference on Inorganic-Bonded Composite Materials Conference, Vancouver, BC, USA, 10-13 October 2004; University of Idaho: Moscow, ID, USA, 2004.

34. Drake, J.E.; Davis, S.C.; Raetz, L.M.; DeLucia, E.H. Mechanisms of age-related changes in forest production: The influence of physiological and successional changes. Glob. Change Biol. 2010, $17,1522-1535$.

35. Aber, J.D.; Federer, C.A. A generalized, lumped-parameter model of photosynthesis, evapotranspiration and net primary production in temperate and boreal forest ecosystems. Oecologia 1992, 92, 463-474.

36. Aber, J.D.; Ollinger, S.V.; Driscall, C.T. Modeling nitrogen saturation in forest ecosystems in response to land use and atmospheric deposition. Ecol. Model. 1997, 101, 61-78. 
37. Davis, S.C.; Hessl, A.E.; Thomas, R.B. A modified nitrogen budget for temperate deciduous forests in an advanced stage of nitrogen saturation. Glob. Biogeochem. Cycle 2008, 22, doi:10.1029/2008GB003187.

38. Ollinger, S.V.; Aber, J.D.; Reich, P.B. Simulating ozone effects on forest productivity: Interactions among leaf-, canopy-, and stand-level processes. Ecol. Appl. 1997, 7, 1237-1251.

39. Ollinger, S.V.; Aber, J.D.; Reich, P.B.; Freuder, R.J. Interactive effects of nitrogen deposition, tropospheric ozone, elevated $\mathrm{CO}_{2}$ and land use history on the carbon dynamics of northern hardwood forests. Glob. Change Biol. 2002, 8, 545-562.

40. Albani, M.; Moore, D.; Hurtt, G.C.; Moorcroft, P.R. The contributions of land-use change, $\mathrm{CO}_{2}$ fertilization, and climate variability to the Eastern US carbon sink. Glob. Change Biol. 2006, 12, 2370-2390.

41. Medvigy, D.; Wofsy, S.C.; Munger, J.W.; Hollinger, D.Y.; Moorcroft, P.R. Mechanistic scaling of ecosystem function and dynamics in space and time: The Ecosystem Demography model version 2. J. Geophys. Res. 2009, 114, doi:10.1029/2008JG000812.

42. Moorcroft, P.R.; Hurtt, G.C.; Pacala, S.W. A method for scaling vegetation dynamics: The ecosystem demography model (ED). Ecol. Monogr. 2001, 74, 557-586.

43. McNulty, S.G.; Vose, J.M.; Swank, W.T. Regional hydrologic response of loblolly pine to air temperature and precipitation changes. J. Am. Water Resour. Assoc. 1997, 33, 1011-1022.

44. Wang, D.; LeBauer, D.S.; Dietze, M.C. Predicted Yields of Short-Rotation Hybrid Poplar (Populus spp.) for the Contiguous US; Working Paper; Energy Biosciences Institute, University of Illinois: Urbana, IL, USA, 2011.

45. Strong, T.; Hansen, E.A. Hybrid poplar spacing/productivity relations in short rotation intensive culture plantations. Biomass. Bioenerg. 1993, 4, 255-261.

46. DeBell, D.S.; Harrington, C.A. Productivity of Populus in monoclonal and polyclonal blocks at three spacings. Can. J. For. Res. 1997, 27, 978-985.

47. Netzer, D.A.; Tolsted, D.N.; Ostry, M.E.; Isebrands, J.G.; Riemenschneider, D.E.; Ward, K.T. Growth, Yield, and Disease Resistance of 7- to 12-year-old Poplar Clones in the North Central United States; Department of Agriculture, Forest Service, North Central Research Station: St. Paul, MN, USA, 2002; p. 31.

48. Goldewijk, K. Estimating global land use change over the past 300 years: The HYDE database. Glob. Biogeochem.Cycle 2001, 15, 417-433.

49. Goldewijk, K.; Van Deusen, P.; Bouwman, A.F. Mapping contemporary global cropland and grassland distributions on a $5 \times 5$ minute resolution. J. Land Use Sci. 2007, 2, 167-190.

50. Olson, D.M.; Dinerstein, E. The Global 200: A representation approach to conserving the earth's most biologically valuable ecoregions. Conserv. Biol. 1998, 12, 502-515.

51. Balboa-Murias, M.A.; Rodriguez-Soalleiro, R.; Merino, A.; Alvarez-Gonzalez, J.G. Temporal variations and distribution of carbon stocks in aboveground biomass of radiata pine and maritime pine pure stands under different silvicultural alternatives. For. Ecol. Manag. 2005, 237, 29-38.

52. Ericksson, E.; Gillespie, A.R.; Gustavsson, L.; Langvall, O.; Olsson, M.; Sathre, R.; Stendahl, J. Integrated carbon analysis of forest management practices and wood substitution. Can. J. For. Res. 2007, 37, 671-681. 
53. Adegbidi, H.G.; Jokela, E.J.; Comerforn, N.B. Factors influencing production efficiency of intensively managed loblolly pine plantations in a 1- to 4-year-old chronosequence. For. Ecol. Manag. 2005, 218, 245-258.

54. Albaugh, T.J.; Allen, L.H.; Dougherty, P.M.; Johnsen, K.H. Long term growth responses of loblolly pine to optimal nutrient and water resource availability. For. Ecol. Manag. 2004, 192, 3-19.

55. Borders, B.E.; Will, R.E.; Marewitz, D.; Clark, A.; Hendrick, R.; Teskey, R.O.; Zhang, Y. Effect of complete competition control and annual fertilization on stem growth and canopy relations for a chronosequence of loblolly pine plantations in the lower coastal plain of Georgia. For. Ecol. Manag. 2004, 192, 21-37.

56. Cobb, W.R.; Will, R.E.; Daniels, R.F.; Jacobson, M.A. Aboveground biomass and nitrogen in four short-rotation woody crop species growing with different water and nutrient availabilities. For. Ecol. Manag. 2008, 255, 4032-4039.

57. Coyle, C.R.; Coleman, M.D.; Aubrey, D.P. Above- and below-ground biomass accumulation, production, and distribution of sweetgum and loblolly pine grown with irrigation and fertilization. Can. J. For. Res. 2008, 38, 1335-1348.

58. Ewers, B.E.; Oren, R.; Sperry, J.S. Influence of nutrient versus water supply on hydraulic architecture and water balance in Pinus taeda. Plant Cell Environ. 2000, 23, 1055-1066.

59. Gresham, C.A.; William, T.M. Biomass, Nitrogen, and Phosphorus Accumulation in 4-year-old Intensively Managed Loblolly Pine and Sweetgum Plantations. In General Technical Report SRS48; Department of Agriculture, Forest Service, Southern Research Station: Asheville, NC, USA, 2002; pp. 3-6.

60. Jokela, E.J.; Martin, T.A. Effects of ontogeny and soil nutrient supply on production, allocation, and leaf area effiency in loblolly and slash pine stands. Can. J. For. Res. 2000, 30, 1511-1524.

61. King, J.S.; Albaugh, T.J.; Allen, H.L.; Kress, W. Stand-level allometry in Pinus taeda as affected by irrigation and fertilization. Tree Phys. 1999, 19, 769-778.

62. Samuelson, L.J.; Johnsen, K.H.; Stokes, T. Production, allocation, and stemwood growth efficiency of Pinus taeda L. stands in response to 6 years of intensive management. For. Ecol. Manag. 2004, 192, 59-70.

63. Sartori, F.; Markewitz, D.; Borders, B. Soil carbon storage and nitrogen and phosphorus availability in loblolly pine plantations over 4 to 16 years of herbicide and fertilizer treatments. Biochemistry 2007, 84, 13-30.

64. Will, R.E.; Munger, G.T.; Zhang, Y.; Borders, B.E. Effects of annual fertilization and complete competition control on current annual increment, foliar development, and growth efficiency of different aged Pinus taeda stands. Can. J. For. Res. 2002, 32, 1728-1740.

65. Makeschin, F. Short rotation forestry in Central and Northern Europe-introduction and conclusions. For. Ecol. Manag. 1999, 121, 1-7.

66. Mitchell, C.P. Ecophysiology of short rotation forest crops. Biomass Bioenergy 1992, 2, $25-37$.

67. Weih, M. Intensive short rotation forestry in boreal climates: Present and future perspectives. Can. J. For. Res. 2004, 34, 1369-1378.

68. BETY-db, Urbana, IL, USA, 2011. Available online: www.ebi-forecast.igb.uiuc.edu (accessed on 10 March 2011). 
69. Heilman, P.E.; Ekuan, G.; Fogle, D. Above- and below-ground biomass and fine roots of 4-year-old hybrids of Populus trichocarpa $\times$ Populus deltoides and parental species in short-rotation culture. Can. J. For. Res. 1994, 24, 1186-1192.

70. Scarascia-Mugnozza, G.E.; Ceulemans, R; Heilman, P.E.; Isebrands, J.G.; Stettler, R.F.; Hinckley, T.M. Production physiology and morphology of Populus species and their hydrids grown under short rotation II: Biomass components and harvest index of hybrid and parental species clones. Can. J. For. Res. 1997, 27, 285-294.

71. Dowell, R.C.; Gibbins, D.; Rhoads, J.L.; Pallardy, S.G. Biomass production physiology and soil carbon dynamics in short-rotation-grown Populus deltoides and P. deltoides $\times P$. nigra hybrids. For. Ecol. Manag. 2009, 257, 134-142.

72. Aylott, M.J.; Casella, E.; Tubby, I.; Street, N.R.; Smith, P.; Taylor, G. Yield and spatial supply of bioenergy poplar and willow short-rotation coppice in the UK. New Phytol. 2008, 178, 258-270.

73. DOE. Breaking the biological barriers to cellulosic ethanol: A joint research agenda. Report from the December 2005 Workshop; US Department of Energy: Oak Ridge, TN, USA, 2006.

74. Mitchell, C.P.; Stevens, E.A.; Watters, M.P. Short-rotation forestry-Operations, productivity and costs based on experience gained in the UK. For. Ecol. Manag. 1999, 121, 123-136.

75. Kopp, R.F.; Abrahamson, L.P.; White, E.H.; Volk, T.A.; Nowak, C.A.; Fillhart, R.C. Willow biomass production during ten successive annual harvests. Biomass Bioenergy 2001, 20, 1-7.

76. Randall, G.; Johnson, G.; Vetch, J.; Bickell, M. Willow Biomass Production as Affected by Time and Rate of N; College of Food, Agriculture and Natural Resource Sciences: Saint Paul, MN, USA, 2010.

77. Serapiglia, M.J.; Cameron, K.D.; Stipanovic, A.J.; Smart, L.B. Analysis of biomass composition using high-resolution thermogravimetric analysis and percent bark content for the selection of shrub willow bioenergy crop varieties. Bioenerg. Res. 2009, 2, 1-9.

78. Milbrandt, A. A Geographic Perspective on the Current Biomass Resource Availability in the United States; Technical Report NREL/TP 560-39181; National Renewable Energy Laboratory: Golden, CO, USA, 2005.

79. Ralevic, P.; Ryans, M.; Cormier, D. Assessing forest biomass for bioenergy: Operational challenges and cost considerations. For. Chron. 2010, 86, 43-50.

80. DOE. US Billion-Ton Update: Biomass Supply for a Bioenergy and Bioproducts Industry. Perlack, R.D., Stokes, B.J., Leads; U.S. Department of Energy, Oak Ridge National Laboratory: Oak Ridge, TN, USA, 2011; p. 227.

81. Perlack, R.D.; Wright, L.L.; Turhollow, A.F.; Graham, R.L. Biomass as Feedstock for $a$ Bioenergy and Bioproducts Industry: The Technical Feasibility of a Billion-Ton Annual Supply; US Department of Energy, Oak Ridge National Laboratory: Oak Ridge, TN, USA, 2005.

82. Gan, J.; Smith, C. Co-benefits of utilizing logging residues for bioenergy production: The case for East Texas, USA. Biomass Bioenergy 2007, 31, 623-630.

83. Ackom, E.K.; Mabee, W.E.; Saddler, J.N. Industrial sustainability of competing wood energy options in Canada. Appl. Biochem. Biotechnol. 2010, 162, 2259-2272.

84. Galik, C.S.; Abt, R.C.; Wu, Y. Forest biomass supply in the Southeastern Unitied StatesImplications for inudstrial roundwood and bioenergy production. J. For. 2009, 107, 69-77. 
85. Lattimore, B.; Smith, C.T.; Titus, B.D.; Stupak, I.; Egnell, G. Environmental factors in woodfuel production: Opportunities, risks, and criteria and indicators for sustainable practices. Biomass Bioenergy 2009, 33, 1321-1342.

86. Powers, R.F.; Andrew, S.D.; Sanchez, F.G.; Voldseth, R.A.; Page-Dumroese, D.; Elioff, J.D.; Stone, D.M. The North American long-term soil productivity experiment: Findings from the first decade of research. For. Ecol. Manag. 2005, 220, 31-50.

87. Johnson, D.W.; Knoepp, J.D.; Swank, W.T.; Shan, J.; Morris, L.A.; van Lear, D.H.; Kapeluck, P.R. Effects of forest management on soil carbon: Results of some long-term resampling studies. Environ. Pollut. 2002, 116, S201-S208.

88. Laiho, R.; Sanchez, F.; Tiarks, A.; Dougherty, P.; Trettin, C. Impacts of intensive forestry on early rotation trends in site carbon pools in the southeastern US. For. Ecol. Manag. 2003, 174, 177-189.

89. DOE. Agricultural Chemicals: Fertilizers. In Energy and Environmental Profile of the U.S. Chemical Industry; US Department of Energy: Oak Ridge, TN, USA, 2000.

90. West, T.O.; Marland, G. A synthesis of carbon sequestration, carbon emissions and net carbon fluxes in agriculture: Comparing tillage practices in the United States. Agric. Ecosyst. Environ. 2001, 1312, 1-16.

91. Kluender, R.; Lortz, D.; McCoy, W.; Stokes, B.; Klepac, J. Removal intensity and tree size effects on harvesting cost and profitability. For. Prod. J. 1998, 48, 54-59.

92. EIA State Energy Data System. US Department of Energy: Washington, DC, USA, 2011. Available online: http://www.eia.doe.gov/emeu/states/sep_fuel/html/fuel_mg.html (accessed on 19 August 2011).

93. Anderson-Teixeira, K.J.; DeLucia, E.H. The greenhouse gas value of ecosystems. Glob. Change Biol. 2011, 17, 425-438.

94. Fargione, J.; Hill, J.; Tilman, D.; Polasky, S.; Hawthorne, P. Land clearing and the biofuel carbon debt. Science 2008, 319, 1235-1238.

95. Davis, S.C.; Anderson-Teixeira, K.J.; DeLucia, E.H. Life-cycle analysis and the ecology of biofuels. Trends Plant Sci. 2009, 14, 140-146.

96. Searchinger, T.; Heimlich, R.; Houghton, R.A.; Dong, F.; Elobeid, A.; Fabiosa, A.; Tokgoz, S.; Hayes, D.; Yu, T.-H. Use of US croplands for biofuels increases greenhouse gases through emissions from land-use change. Science 2008, 319, 1238-1240.

97. Farrell, A.E.; Plevin, R.J.; Turner, B.T.; Jones, A.D.; O’Hare, M.; Kammen, D.M. Ethanol can contribute to energy and environmental goals. Science 2006, 311, 506-508.

98. Davis, S.C.; House, J.I.; Diaz-Chavez, R.A.; Molnar, A.; Valin, H.; DeLucia, E.H. How can land-use modelling tools inform bioenergy policies? Interface Focus 2011, 1, 212-223.

(C) 2012 by the authors; licensee MDPI, Basel, Switzerland. This article is an open access article distributed under the terms and conditions of the Creative Commons Attribution license (http://creativecommons.org/licenses/by/3.0/). 